\title{
The End(S) OF SELF-REgulation?
}

\section{RICHARD F. DEVLIN* and PORTER HEFFERNAN ${ }^{* *}$}

Self-regulation is a sacred cow of the Canadian legal profession. The authors question this assumption on several levels and ask whether, in a liberal democratic society such as Canada, self-regulation really is in the public interest. The advantages and disadvantages of self-regulation are discussed in the context of other Commonwealth nations who have moved away from this type of regulatory structure. Though the self-regulation debate has been traditionally viewed as a "one way or the other" argument, calibrated regulation seems to be a possibility in Canada and, in fact, steps have already been taken in this direction. Devlin and Heffernan conclude by proposing the creation of a Task ForceThe Sponsors' Table on the Regulation of the Legal Profession - to reconsider the present state and future possibility of recalibrated regulation in Canada.
Il y a plusieurs raisons pour lesquelles le système juridique actuel du Canada ne fonctionne pas, et toutes mènent à la question de savoir si l'autorégulation est vraiment dans notre meilleur intérêt. Les avantages et inconvénients de l'autorégulation sont discutés dans le contexte d'autres pays du Commonwealth qui se sont éloignés de ce type de structure réglementaire. Bien que le débat autour de l'autorégulation ait traditionnellement été considéré comme étant un argument du type "d'une manière ou d'une autre », la régulation étalonnée semble une possibilité au Canada et d'ailleurs, des mesures ont déjà été prises en ce sens. Devlin et Heffernan ont conclu en proposant la création d'un groupe de travail - Table des commanditaires sur la régulation de la profession juridique - pour réexaminer l'état actuel et la possibilité future d'une régulation étalonnée au Canada.

\section{TABLE OF CONTENTS}

I. INTRODUCTION . . . . . . . . . . . . . . . . . . . . . 170

II. RumblingS IN THE PEACEABle KINGDOM $\ldots \ldots \ldots \ldots \ldots \ldots \ldots \ldots \ldots$

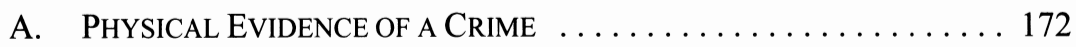

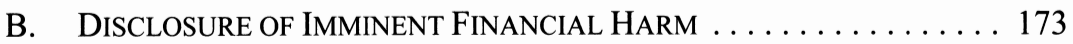

C. PROTECTION OF THE PUBLIC FROM INCOMPETENT LAWYERS $\ldots \ldots 174$

D. Sexual Relations with a Client $\ldots \ldots \ldots \ldots \ldots \ldots \ldots \ldots$

E. DisCIPLINE IN THE PROTECTION OF

VictiMS OF RESIDENTIAL SCHOOLS $\ldots \ldots \ldots \ldots \ldots \ldots \ldots . \ldots 176$

F. BILling AND FEES IN the ReSidential School CASES . . . . . . . 177

G. MANDATORY CONTINUING LEgAL EdUCATION ........... 178

H. FEES . . . . . . . . . . . . . . . . . . . . . . . . . . . 179

I. SELF-REPRESENTED LITIGANTS IN COURT $\ldots \ldots \ldots \ldots \ldots \ldots \ldots 181$

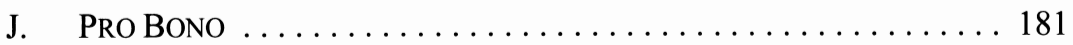

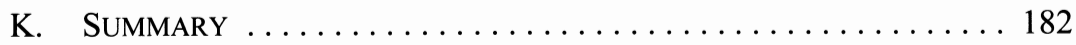

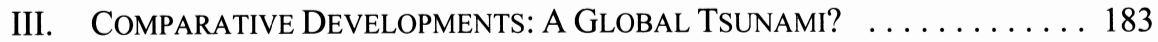

IV. THE WELL-TILLED FIELD:

ARguments PRo and Con Self-REgulation . . . . . . . . . . . . 185

A. ARgUMENTS IN FAVOUR $\ldots \ldots \ldots \ldots \ldots \ldots \ldots \ldots \ldots \ldots$

* Associate Dean, Graduate Studies and Research, Dalhousie Law School; University Research Professor, Dalhousie University.

** LL.B., Dalhousie Law School; LL.M. Candidate, Dalhousie Law School. We have benefited greatly from the critical insights of our colleagues Bruce Archibald, Alexandra Dobrowolsky, Meinhard Doelle, Jocelyn Downie, and Lorraine Lafferty. Special thanks to Kate Darling for her early research for this article and the Dalhousie University Travel Research Fund which enabled Professor Devlin to conduct interviews in New Zealand, Australia, South Africa, Scotland, and England and Wales. The technical support of Molly Ross and Geordie Lounsbury is deeply appreciated. 
B. Arguments Against . . . . . . . . . . . . . . . . . . 189

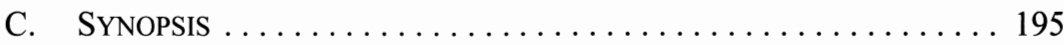

V. ENLARGING THE REGULATORY IMAGINATION:

CALIBRATEd REgUlATION AND ITS OPTIONS . . . . . . . . . . . . . . . 196

VI. Regulatory Laggards: Why the CanAdian Silence? . . . . . . . . 206

A. Vocalization of CONSUMER DisSATISFACTION . . . . . . . 206

B. Disaggregation of the Legal Profession . . . . . . . . 207

C. Paucity of Scholarly Research . . . . . . . . . . . . . 207

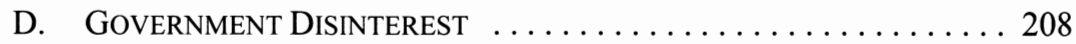

E. The Shadow of the Courts $\ldots \ldots \ldots \ldots \ldots \ldots \ldots \ldots \ldots \ldots$

F. Cadre of Professional Regulators . . . . . . . . . . . . . . 208

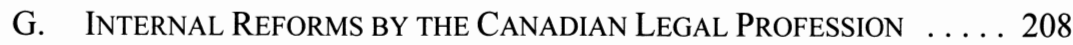

VII. CODA: TRACES of CALIBRATEd REgulation . . . . . . . . . . . . . . . 209

VIII. CONCLUSION: THE SPONSORS' TABLE ON THE

Regulation of the Legal Profession in CANADA . . . . . . . . 211

APPENDIX I: THE SPONSORS' TABLE ON THE

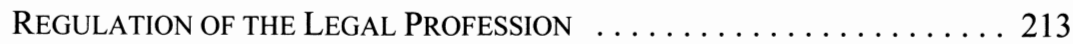

\section{INTRODUCTION}

There is something curious going on in Canada. All around the world, jurisdictions are reconsidering and ultimately abandoning self-regulation as a model for the governance of the legal profession. ${ }^{1}$ Whether it be Australia, New Zealand, Scotland, England and Wales, South Africa, or Ireland, a wide range of advanced liberal democratic societies have assessed self-regulation and found it wanting as an defensible regime. ${ }^{2}$ By contrast, in Canada, self-

Julia Black in her field-defining essay, "Critical Reflections on Regulation" (2002) 27 Austl. J. Legal Phil. 1 at 25, defines regulation as "the intentional activity of attempting to control, order or influence the behavior of others." Christine Parker et al., eds., "Introduction," Regulating Law (Toronto: Oxford University Press, 2004) 1 [Parker et al., RL]: builds on this definition by arguing that "[i]t incorporates three basic requirements for a regulatory regime: the setting of standards; processes for monitoring compliance with the standards; and mechanisms for enforcing the standards" (at 1). But see Liora Salter, "Speaking of Regulation: Three Discourses" in Michael McConkey \& Patrice Dutil, eds., Dreaming of the Regulatory Village: Speaking of the Regulatory State (Toronto: Institute of Public Administration of Canada, 2006) at 130, who argues that there is much confusion about what we are talking about when we invoke "regulation." In Pearlman v. Manitoba Law Society Judicial Committee, [1991] 2 S.C.R. 869 at 886 [Pearlman], the Supreme Court of Canada indicated that in its view, self-governance has three dimensions: control over (1) who can practice law (2) the conditions or requirements placed on those who practice law and (3) the means of enforcing those conditions/requirements. See also William $\mathrm{H}$. Hurlburt, The Self-Regulation of the Legal Profession in Canada and in England and Wales (Edmonton: Law Society of Alberta/Alberta Law Reform Institute, 2000) at 3; Mary Seneviratne, The Legal Profession: Regulation and the Consumer (Toronto: Carswell, 1999) at 25-31 [Seneviratne, Legal Profession]. Sometimes commentators draw a distinction between self-governance and self-regulation. Others draw a distinction between "autonomy (self-government), autarchy (self-management) and autocriny (self-jurisdiction)." Vittorio Olgiati, "Can Legal Ethics Become a Matter of Academic Teaching? Critical Observations from a Late-Modern Perspective" in Kim Economides, ed., Ethical Challenges to Legal Education and Conduct (Oxford: Hart, 1998) 83 at 85. For the purposes of this essay, we propose to use the terms self-regulation and self-governance interchangeably.

For a general overview see Janice Mucalov, "Self-Governance: Walking the Tightrope" CBA National 13:6 (October 2004) 16. In this article we have decided not to extensively address the situation in the United States as this is a complex system that would warrant a paper in itself. Generally speaking, authority over admissions and discipline rests with the Supreme Courts of each state, a fundamentally 
regulation by the legal profession appears to be a sacred cow. ${ }^{3}$ Governments, the general public, the judiciary, and the profession itself all appear to believe that self-regulation is de facto and de jure the only game in town and that substantive consideration of alternatives would be unnecessary, fruitless, and pointless. ${ }^{4}$ For example, in Nova Scotia in the early 2000 s, it was decided that it was necessary to modernize the legal regime governing the legal profession, as the Barristers and Solicitors Act ${ }^{5}$ was fast closing in on its 150 th birthday. Not once in the process was there any serious discussion of the appropriateness, or otherwise, of self-regulation. ${ }^{6}$ This is especially noteworthy because, at the same time, the Government of Nova Scotia was putting a great deal of emphasis on its "Competitiveness and Compliance Initiative" with its "Better Regulation, Everyone's Business" seal of approval. ${ }^{7}$ By contrast, in all the other previously-mentioned jurisdictions, there have been extended discussions, protracted consultations, and passionate (sometimes vitriolic) debates on the topic. While it may be tempting to suggest that this is hardly surprising in a small (perhaps insular) province like Nova Scotia, it seems that the situation in every other jurisdiction in Canada is the same — the status quo of self-regulation is entrenched and unassailable. ${ }^{8}$

In this modest article we attempt to unpack this mystery in several stages. First, to explain why such an inquiry might be justified, we briefly identify a number of situations and circumstances which suggest that not all is well in Canada. Second, to demonstrate that options are available and that change is possible, we briefly outline the emergence of alternative regulatory structures in several other jurisdictions around the globe. Third, on a conceptual level, we identify the various arguments traditionally offered for and against selfregulation. Fourth, the article moves to the level of institutional design in which we introduce the concept of calibrated regulation and map out a number of regulatory options that can serve as heuristic devices to determine the pedigree of the self-regulatory model. Fifth, we tentatively identify some variables that might explain the relative quietude of Canada on this important topic. In the conclusion, we return to the core question as to the end(s) of self-

different system than those discussed here. See generally Thomas D. Morgan \& Ronald D. Rotunda, Professional Responsibility: Problems and Materials, 6th ed. (Westbury, N.Y.: Foundation Press, 1995) at 35 .

3 See Hurlburt, supra note 1.

$4 \quad$ For example, in Pearlman, Iacobucci J. quoted a 1980 report by the Ontario Ministry of the Attorney General ("The Report of the Professional Organizations Committee," Study Paper (Toronto: Queen's Printer, 1980)), which stated that " $[t]$ he regulation of professional practice ... involves the creation of valuable rights [i.e. for lawyers]; and it is directed toward the protection of vulnerable interests [i.e., of the public]" (Pearlman, supra note 1 at 887 ).

R.S.N.S. 1989 , c. 30.

6 Richard Devlin \& Jocelyn Downie, "Self-Regulation in the Shire" The Society Record 22:1 (February 2004) 18.

$7 \quad$ See e.g. Nova Scotia Environment and Labour, "Competitiveness and Compliance Initiative: Annual Report 2006" (Halifax: Office of Competitiveness and Compliance, 2006), online: Nova Scotia Environment and Labour <http://www.gov.ns.ca/nse/cci/docs/CCI_2005-2006_AnnualReport.pdf>.

8 A second example of the power of the self-regulation zeitgeist is found in the debate over the regulation of paralegals in Ontario. Despite the fact that former Supreme Court Justice Peter Cory recommended in an independent report that paralegals should be permitted to establish their own regulatory regime, the Law Society of Upper Canada (LSUC) insisted that it should have regulatory authority over paralegals (Ontario Ministry of the Attorney General, A Framework for Regulating Paralegal Practice in Ontario by Peter de C. Cory (Toronto: Ontario Ministry of the Attorney General, 2000)). The government of Ontario rejected Cory J.'s analysis and accepted the position advocated by the LSUC. On 1 May 2007, the LSUC became responsible for the regulation of paralegals in the province through an amendment to the Law Society Act: Access to Justice Act, 2006, R.S.O. 2006, c. 21. 
regulation and propose the creation of a national taskforce, The Sponsors' Table on the Regulation of the Legal Profession.

\section{Rumblings in the Peaceable Kingdom}

We are great believers in the aphorism "if it ain't broke, don't fix it." However this notion only holds true if one is willing to genuinely consider whether the object in question is working or not. In this section, we want to identify, perhaps à la David Letterman, ten reasons why Canadians might be concerned that the regulation of the legal system might not be working as well as one would want in a liberal democratic society. These misgivings run the gamut of the regulatory spectrum from establishing standards, through monitoring, to enforcement.

\section{A. Physical Evidence of a CRime}

The problem of how a lawyer should deal with physical evidence of a client's crime that comes into their possession is not a new one. ${ }^{9}$ However, it came into the spotlight once again in the last decade with the case of Mr. Ken Murray. Murray was charged with obstruction of justice for failing to turn over damning evidence of the guilt of his client, Paul Bernardo. In the end, Murray was acquitted of the obstruction charge, with the trial judge finding that although his actions had the tendency to obstruct justice, he lacked the required element of intent. ${ }^{10}$ This did not bring an end to Murray's problems, however. After his acquittal, the Law Society of Upper Canada (LSUC) charged him with professional misconduct, only to drop the charges before they were resolved. ${ }^{11}$

Murray's actions and their consequences reverberated throughout the profession. The LSUC formed a committee to review its rules of practice soon after the decision to drop the misconduct charge, seeking both compliance with the holding of the court in Murray, and assurance that lawyers facing a similar situation in the future would have adequate ethical guidance. ${ }^{12}$ Other provinces watched the Ontario Special Committee while making their own moves to reform. ${ }^{13}$ For example, in Nova Scotia, a subcommittee was formed to consider the problem, and worked for two years to produce a commentary to r. 21 of the Legal Ethics Handbook, dealing with a lawyer's duty to the administration of justice. ${ }^{14}$ The recommended

See Austin M. Cooper, “The Ken Murray Case: Defence Counsel's Dilemma”(2003) 47 Crim. L.Q. 141 at $141-42$.

R. v. Murray (2000), 48 O.R. (3d) 544 (Ont. Sup. Ct.) [Murray]; see also ibid. at 147.

"Law Society of Upper Canada Clears Ken Murray" CBC News (29 November 2000), online: CBC News $<$ http://www.cbc.ca/news/story/2000/11/29/001129murray2.html $>$.

Notably the LSUC, ibid. The LSUC committee delivered its report in March 2002 (The Law Society of Upper Canada, Special Committee on Lawyers' Duties with Respect to Property Relevant to a Crime or Offence, "Report to Convocation" (21 March 2002), online: The LSUC <http://www.lsuc.on.ca/ media/convmar02_physicalevidence.pdf $>$ [LSUC, Special Committee Report]).

See Nova Scotia Barristers' Society, Professional Responsibility Today, No. 3 (April 2002); Alberta was also considered by both the Ontario and Nova Scotia Committees, as they had had a rule in their code on the subject for some time before the Ontario reform efforts began; see LSUC, Special Committee Report, $i b i d$.

Nova Scotia Barristers' Society, Legal Ethics Handbook, online: Nova Scotia Barristers' Society $<$ http://www.nsbs.org/legalethics/toc.htm> [Nova Scotia, Handbook]; Nova Scotia Barristers' Society, "2003 Annual Report" and "2004 Annual Report," online: Nova Scotia Barristers' Society 
reform was submitted to the bar council and the executive committee of the Barristers' Society for approval, at which point it fell quietly off the radar. The Ontario reform seems to have suffered the same fate. ${ }^{15}$ The Nova Scotia Handbook still contains no guidance for counsel who are handed physical evidence of a crime, and it shares this in common with the handbooks of all other provinces except Alberta. ${ }^{16}$ Despite the pressing and complex nature of this problem, lawyers who encounter it today have little more assistance at their disposal than did Murray in 1993.

\section{B. DisClosure OF IMMINENT FinANCIAL HARM}

There are very few exceptions to the duty of confidentiality as outlined in the codes of professional conduct across the country. One of these, the "future harm" exception, variously either requires or permits disclosure of confidential information where the disclosure is necessary to prevent future harm to a third party. This exception is framed in different ways in almost every jurisdiction, ranging from the broad New Brunswick provision, which gives the lawyer discretion to reveal confidential information relating to criminal or fraudulent acts, and requires disclosure of serious crimes that are about to be committed, ${ }^{17}$ to the very restrictive British Columbia provision permitting a lawyer to reveal information only where necessary to prevent a crime involving death or serious bodily harm. ${ }^{18}$

What is striking is that while all jurisdictions in some way recognize a serious violent crime as reason enough to breach confidentiality, few jurisdictions permit disclosure to prevent serious financial harm, and none require it. Although revisions to the Ontario rules recognize that disclosure might be necessary to prevent non-criminal future harm, they still focus on serious bodily harm or death. This is particularly surprising in light of the numerous high-profile instances of financial mismanagement which have come to light in recent years, which routinely involve lawyers at some level, and in some cases, have cost investors their

$<$ http://www.nsbs.org/annualReport.php>

The LSUC, Special Committee Report, supra note 12, recommended a new rule (r. 4.01(10)) be added to the Rules of Professional Conduct, but to date, it has not been incorporated (The Law Society of Upper Canada, Rules of Professional Conduct (1 November 2000), online: The LSUC $<$ http://www.lsuc.on.ca/regulation/a/profconduct/>).

16 The Law Society of Alberta, Code of Professional Conduct (1 February 2007), online: The Law Society of Alberta <http://www.lawsocietyalberta.com/files/code.pdf $>$ : "A lawyer must not counsel or participate in ... the concealment of property having potential evidentiary value in a criminal proceeding" (c.10, r. 20). The commentary to r. 20 expands on the means of compliance with the rule: "[w]hile a lawyer has no obligation to disclose the mere existence of such evidence, it would be unethical to accept possession of it and then conceal or destroy it. The lawyer must therefore advise someone wishing to deliver potential evidence that, if possession is accepted by the lawyer, it will be necessary to turn the evidence over to appropriate authorities (unless it consists of communications or documents that are privileged)."

17 Law Society of New Brunswick, Code of Professional Conduct (1 January 2004)c. 5, r. 8-9, online: Law Society of New Brunswick <http://www.lawsociety-barreau.nb.ca/assets/documents/Code of_professional_conduct_March_2006.pdf $>$. For a full review of the treatment of the future harm exception across the country, see Michel Proulx \& David Layton, Ethics and Canadian Criminal Law (Toronto: Irwin Law, 2001) at 230-50.

18 The Law Society of British Columbia (LSBC), Professional Conduct Handbook (December 2007) c. 5, r. 12, online: The LSBC <http://www.lawsociety.bc.ca/publications_forms/handbook/handbook toc.html>. 
entire life savings. Surely a loss of one's employment and one's retirement income is more catastrophic than broken bones or many other forms of bodily harm.

As Michel Proulx and David Layton note, the exclusion of financial harm has not been an accident. In the recent Ontario reforms, which broadened permissive disclosure to include non-criminal harm, the idea of including financial and other "non-physical harm" was discussed and rejected. ${ }^{19}$ The value judgment, then, is clear: in most jurisdictions, even catastrophic financial harm to a third party does not outweigh the public interest in maintaining the sanctity of the solicitor-client relationship. This principle is even harder to defend when compared to the "self-interest" exception, included in all codes of conduct, which allows a lawyer to reveal such confidences as are necessary to collect a fee. ${ }^{20}$ In some jurisdictions, then, a lawyer can ethically reveal confidential information to collect on a debt of CDN\$2000, but cannot ethically breach confidentiality to prevent the sort of catastrophic financial loss to another outlined above. ${ }^{21}$

\section{Protection of the Public from Incompetent LaWyers}

Between 1991 and 1994 on numerous occasions, Ms. Christina McCullock Finney complained to the Barreau du Quebec about a lawyer, Eric Belhassen, whom she alleged to be incompetent. ${ }^{22}$ The Barreau did very little to help her or deal with Belhassen until 1998 when he was finally struck from the roll. Finney decided that she wanted to sue the Barreau for its failure to protect the public. However she could not find, or afford, a lawyer to take her case, so she became a self-represented litigant. The Barreau invoked the immunity clause in its governing legislation that protected the society and its officers from legal liability so long as they were acting in good faith which, they argued, meant acting without "malice or intent to harm." ${ }^{23}$ In support of this extremely high standard, the Barreau was joined by the Federation of Law Societies, which represents all 14 law societies in Canada, and together they forced Finney to litigate her case all the way to the Supreme Court of Canada. Only at this final stage did she receive the assistance of a pro bono lawyer, Guy Pratte. Despite the phalanx of the law societies, she won. The Supreme Court found that the Barreau did not deal with her concerns in "good faith," and that the standard was not "malice or intent to harm" but rather "recklessness" or "gross or serious carelessness."24

Even in finding for Finney, the Court did not set an impossibly high standard for the Barreau to meet in its duty to the public. A standard of gross carelessness does not require that the Barreau watch over the shoulder of every lawyer, all the time, but rather that it

19 Proulx \& Layton, supra note 17 at 232, citing David Layton, "The Public Safety Exception: Confusing Confidentiality, Privilege and Ethics" (2001) 6 Can. Crim. L. Rev. 217.

20 See Proulx \& Layton, ibid. at 229-30.

21 For further discussion of the adoption of a crime/fraud exemption to the confidentiality rule, see Paul D. Paton, "The Independence of the Bar and the Public Interest Imperative: Lawyers as Gatekeepers, Whistleblowers, or Instruments of State Enforcement?" in The Law Society of Upper Canada, In the Public Interest: The Report and Research Papers of the Law Society of Upper Canada's Task Force on the Rule of Law and the Independence of the Bar (Toronto: Irwin Law, 2007) at 175 [LSUC, Public Interest].

22 Finney v. Barreau du Québec, 2004 SCC 36, [2004] 2 S.C.R. 17 at paras. 3-9 [Finney].

$23 \quad$ Ibid. at para. 40.

24 Ibid. 
institute effective, quick processes to deal with complaints as they come in, and to deal with lawyers who are unfit to practice and are therefore a threat to the public, as was Belhassen. The Court's finding that the Barreau had not met this standard in its handling of Finney's complaint is cause for some concern about the effectiveness of the law societies' regulatory and disciplinary processes. Even more disconcerting is the highly adversarial and protectionist stance of the Federation of Law Societies which, it seems, was intervening on behalf of the law societies' interest rather than the public interest.

\section{Sexual Relations with a Client}

Practising lawyers in Canada were recently reminded that sexual and romantic relationships with clients is an area which the legal profession has yet to come down on quite so hard as the regulating bodies of other professions. In December 2005, one of Canada's leading lawyers, George Hunter, a senior partner at Borden Ladner Gervais LLP in Ottawa, the Treasurer of the LSUC, and the president of the Canadian Federation of Law Societies stepped down from his posts and took a leave of absence from his firm, citing the breakdown of his marriage, and his concern for the well-being of his children. ${ }^{25}$ Nine months later, it came to light that the LSUC was investigating him for potential breaches of the Code of Ethics in relation to a long-term sexual relationship he had had with a client whom he represented through a lengthy divorce. ${ }^{26}$ Ultimately, Hunter was charged with misconduct in relation to his actions, and handed a two month suspension as a result. ${ }^{27}$

In deciding Hunter's case the panel looked to r. 2.04 of the Ontario Rules of Professional Conduct for guidance. ${ }^{28}$ Rule 2.04 , like the rules of most other law societies in Canada, does not explicitly prohibit sexual or close personal relations with clients, but it does stress the potential conflict of interest which can arise in such situations. It is important to emphasize that Hunter, when it became clear that his relationship with the client was both about to end and inevitably become public, attempted to have the client sign a release and acknowledgement stating that she was aware of r. 2.04, understood the potential conflict, and had consented to his continued representation of her under those circumstances. ${ }^{29}$ Over the subsequent days, Hunter continued to request more declarations and statements of a similar nature from the client, all without suggesting that she seek independent legal advice. ${ }^{30}$ The panel stressed the inappropriateness of this behaviour in determining that two months represented an appropriate sentence for Hunter. ${ }^{31}$

Christin Schmitz \& John Jaffey, "Hunter Quits as Law Society of Upper Canada Treasurer" Lawyers Weekly (16 December 2005), online: The Lawyers Weekly <http://www.lawyersweekly.ca/index.php? section $=$ article $\&$ articleid $=203>$. September 2006), online: The Lawyers Weekly <http://www.lawyersweekly.ca/index.php?section= article\&articleid=347> [Schmitz, "Law Society"]. client" Lawyers Weekly (16 February 2007), online: The Lawyers Weekly <http://www.lawyersweekly. ca/index.php?section=article\&articleid=424> [Schmitz, "Ex-Law Society"]. 
Hunter's case highlights two areas of concern in the regulation of the legal profession. First, as several commentators have noted, there have been objections that the sentence handed down - a two month suspension - was not sufficiently severe in this case. ${ }^{32}$ One lawyer in a comment to Lawyers Weekly "called the ... punishment 'a slap on the wrist' that will not deter lawyers from engaging in inappropriate sexual relationships with vulnerable clients. ${ }^{\prime 33}$ Another suggested that the client, whose name was protected by a publication ban, "was 'forgotten' and 'has not been represented here today." ${ }^{34}$ Finally, the author of the same article, discussing the many supporting character references provided for Hunter, observed "the irony of Benchers urging three fellow Benchers to mete out the mildest possible sentence to a former Bencher guilty of conflict of interest. ${ }^{, 35}$

Second, as the comments of both the panel and commentators on the case make clear, r. 2.04 does not clearly delineate acceptable and unacceptable relationships with clients, but instead leaves much to subjective judgment. ${ }^{36}$ The LSUC, in a 2004 reconsideration of its conflict of interest rules, declined to adopt the zero-tolerance rule embraced by both the medical profession in Canada and the legal profession in the United States. ${ }^{37}$ The resulting r. 2.04 arguably does not provide a clear enough statement of the dangers of engaging in such a relationship, leaving it up to the lawyer involved to estimate what steps are necessary to avoid a conflict of interest - a difficult task as Hunter would no doubt agree.

\title{
E. Discipline in the Protection Of Victims of Residential SCHOOLS
}

The cultural, psychological, and physical harm done to generations of Aboriginal people by the Canadian Residential Schools system has now been acknowledged by the federal government, and efforts at compensation and reconciliation have begun. This is so in large part because of the actions of advocates for the victims, including many lawyers. Efforts to reach a resolution and settlement between the victims and the federal government have given rise to two distinct issues worth discussing here: first, ethical concerns in the solicitation of plaintiffs for the original class action suits filed against the government; and second, concerns relating to the fees to be paid to lawyers who have represented those same class action plaintiffs over the years leading up to the settlement.

Saskatchewan lawyer Anthony Merchant has been at the heart of both of these areas of controversy. Without intending to single Merchant or his firm out for special criticism, he nonetheless provides an excellent example of the concerns raised by both of these issues. The first issue is Merchant's 2002 disciplinary conviction, which found him guilty of conduct unbecoming for corresponding in a manner reasonably capable of misleading the recipient in respect of his solicitation letters to potential residential school survivors. ${ }^{38}$ More recently,

\author{
Schmitz, "Ex-Law Society," supra note 27. \\ Ibid. \\ Ibid. \\ Ibid. \\ Schmitz, "Law Society," supra note 26. \\ Ibid. \\ Law Society of Saskatchewan v. Merchant, [2000] L.S.D.D. No. 24 (QL) [Merchant].
}


he has drawn both praise and criticism for the sum his firm expects to receive for its representation of those same school survivors: between CDN\$28 and 43 million. ${ }^{39}$

For the 2002 convictions by the Law Society of Saskatchewan (LSS), Merchant was fined CDN\$5,000 and $\$ 10,000$ in costs by the LSS, and was reprimanded..$^{40}$ This seems a relatively minor sanction, particularly in light of the amount in fees that is now clearly at stake. Unfortunately, the finding and sentence did not alter Merchant's style of practice; this was not to be his last encounter with the disciplinary process. In 2006, he was again convicted of two counts of conduct unbecoming: first on the basis of trust fund irregularities; and second, on another solicitation letter deemed by the panel to be reasonably capable of misleading the recipient. ${ }^{41}$ In this case, he was fined $\$ 60,000$ and suspended for two weeks. ${ }^{42}$ This case remains before the Saskatchewan Court of Appeal. ${ }^{43}$

It seems then that the sentence initially handed down by the Law Society Disciplinary Committee in the 2002 decision against Merchant was not enough to drive home the ethical problems with his style of solicitation. $\$ 5,000$ was clearly too little - the benefits outweighed the costs. It was what an ethinomicist might describe as an "efficient ethical breach." 44 Perhaps the disciplinary process needs to be reviewed for effectiveness as a mechanism to protect the public in order to drive the point home with the first conviction, rather than the second or third.

\section{F. Billing ANd Fees in the ReSidential Schools CaSeS}

Disciplinary issues aside, many up to and including former Supreme Court Justice Frank Iacobucci have expressed concern with Merchant's billing on the residential schools file. ${ }^{45}$ Opinions of the service provided by his firm are mixed. Some point to the success he has had advocating for the cause of survivors, bringing the issue of residential schools to the forefront of public attention, and securing a settlement from the government. ${ }^{46}$ Others suggest he is "getting rich off the blood, sweat and tears of the people who actually suffered and were tortured at the residential schools." ${ }^{47}$ In any event, there have been serious questions raised about the firm's billing practices and entitlement to the fees they are claiming.

The commission appointed to vet the legal fees as a part of the courts' approval of the settlement package, chaired by Justice Iacobucci, wanted to have the Merchant Law Group

Geoff Kirbyson, "The Big Picture" Canadian Lawyer (August 2007), online: Canadian Lawyer <http:// www.canadianlawyermag.com/index.php?option $=$ com_content\&task=view\&id=142\&ltemid $=18>$. Merchant, supra note 38.

"Lawyer found guilty of "conduct unbecoming"” CBC News (8 February 2006), online: CBC News $<$ http://www.cbc.ca/canada/saskatchewan/story/2006/02/08/merchant-law-society060208.html>.

Jonathon Gatehouse, "Residential Schools Settlement Enriches Lawyer" Maclean's Magazine (11 September 2006), online: The Canadian Encyclopedia $<$ http://thecanadianencyclopedia.com/index.cfm? $\mathrm{PgNm}=\mathrm{TCE} \&$ Params $=$ M1 ARTM0012968>.

Kirbyson, supra note 39.

See e.g. Randal N.M. Graham, Legal Ethics: Theories, Cases, and Professional Regulation (Toronto: Emond Montgomery, 2004) at 192-96, 201-205. On the virtues of "ethinomics" see vii-viii.

Gatehouse, supra note 42.

"Potential huge payday coming for lawyer Merchant" CBC News (21 September 2006), online: CBC News $<$ http://www.cbc.ca/canada/saskatchewan/story/2006/09/21/merchant-profile.html>. Ibid. 
LLP's files reviewed through a forensic audit by accountants from Deloitte Touche. Merchant and his partners allowed the auditors only limited access to selected files before shutting them out with claims of solicitor-client privilege. ${ }^{48}$ Even what the accountants saw in their brief review raised concerns: unusual billings, retainer agreements available for only half of the claimed clients, and an hourly rate of almost double that charged to clients in similar cases. ${ }^{49}$ Other lawyers representing residential schools clients claim to have found their clients included on the Merchant Law Group's client list, with no recollection of having signed retainer agreements. ${ }^{50}$ The Government of Canada requested that Merchant Law Group's fees be reviewed by the Court of Queen's Bench in Saskatchewan, but also requested that this review not delay the claim and payment process. ${ }^{51}$ The request to expedite the claim and payment process was granted, and the settlement agreement, including the portion relating to fees, was approved by the courts on 22 March $2007 . .^{52}$ As of November 2007, the fees of Merchant Law Group had not yet conclusively been settled, although the majority of the controversy surrounding them appears to have quieted now that the claims process is back on track. ${ }^{53}$

Despite the controversy surrounding the Merchant Law Group's fees and billing practices, and despite the concerns raised by a former Supreme Court Justice and forensic auditors, the law societies showed no interest in investigating Merchant's billing practices (Merchant is a member of three law societies). In fact, they supported him in his reliance on solicitor-client privilege to block the government's efforts to verify his billing..$^{54}$ The reality that the law societies seem uninterested in even investigating claims of this nature is cause for serious concern. One would expect, particularly in light of the growing criticism of legal billing practices and fees for legal services more generally, ${ }^{55}$ that the law societies would want to be certain that allegations of this nature were investigated thoroughly rather than simply closing ranks around the lawyer involved without any inquiry into the matter.

\section{G. Mandatory Continuing Legal Education}

Very little has been done to make continuing legal education (CLE) compulsory in Canada. ${ }^{56}$ While there have been some modest developments in both Ontario and British Columbia, it is impossible to describe these as much more than symbolic. Ontario was the first province to implement a system of mandatory reporting of all professional development or CLE activities for practising lawyers. ${ }^{57}$ The expected time practitioners will dedicate to

$48 \quad$ Gatehouse, supra note 42.

$49 \quad$ Ibid.

$50 \quad$ Ibid.

51 Residential Schools Settlement, Official Court Notice, Updates (31 January 2007), online: Crawford Class Action Services <http://www.classactionservices.ca/IRS/updates.htm>.

52 Residential Schools Settlement, Official Court Notice, Updates (22 March 2007), online: Crawford Class Action Services <http://www.classactionservices.ca/IRS/updates.htm>.

$53 \quad$ See Kirbyson, supra note 39.

54 See Gatehouse, supra note 42.

55 See e.g. Alice Woolley, "Time for Change: Unethical Hourly Billing in the Canadian Profession and What Should be Done About It" (2004) 83 Can. Bar Rev. 859 [Woolley, "Time for Change"].

$56 \quad$ See also Hurlburt, supra note 1 at 89.

57 The Law Society implemented its "Minimum Expectations for Professional Development" in 2002 (The Law Society of Upper Canada, "The Minimum Expectations for Professional Development” (2002), online: The LSUC <http://mrc.lsuc.on.ca/jsp/minExpectationforProfDev/index.jsp >). 
professional development work is fairly light: 12 hours of in-course study and 50 hours of self-study per year. ${ }^{58}$ This is not a mandatory quota, but a suggested target. ${ }^{59}$ File-specific research or reading printed materials such as journal articles or law reports will count towards the self-study time.$^{60}$ It is hard to see how this requirement, even if it were made mandatory, would be onerous for any active practising lawyer.

Other provinces have yet to follow even the LSUC's baby steps. The Law Society of Manitoba debated the issue and in the end adopted a system of mandatory reporting of CLE activity, similar in principle and requirements to that in Ontario, which is expected to be implemented in 2008. ${ }^{61}$ British Columbia experimented with a system of mandatory reporting in 2005, accompanied by expectations similar to those in Ontario. Based on the outcome of that experiment, and the report of a task force dedicated to studying the issue, the Law Society of British Columbia (LSBC) hopes to introduce recommendations for a program of mandatory CLE by the end of $2007 .{ }^{62}$ Finally, Quebec introduced a form of mandatory legal education to smooth the transition to the new Civil Code. ${ }^{63}$

That summary is (we believe) a full review of the efforts of Canadian law societies to introduce mandatory CLE. By way of contrast, some form of mandatory continuing education has been adopted by the legal profession throughout much of the U.S., as well as in Australia and New Zealand, and by virtually all of the other Canadian professions. In the Canadian legal profession, however, there seems to be significant resistance to such an idea. But continuing education is vital for any profession that wants to ensure the core competencies of its members. ${ }^{64}$

\section{H. FEES}

Concerns about access to justice and the rising cost of legal services have grown over the last few decades. The issue has moved from the margins of the attention of socially progressive critics to the central focus of major figures in the Canadian justice system. The debate has strong advocates on both sides, both from within and outside the profession. Former Chief Justice of Ontario Roy McMurtry captured the problem in 1999 when he stated that "the major challenge facing the justice system in the next millennium will be the absence of adequate legal advice and legal representation to our society's increasing numbers of disadvantaged. ${ }^{\circ 5}$ Rising fees are of course just one dimension of this problem: as fees rise,

$58 \quad$ Ibid.

59 Ibid.

60 Ibid.

61 Law Society of Manitoba, Communiqué (June 2006), online: Law Society of Manitoba <http://www. lawsociety.mb.ca/communique/communique june06.htm>.

The Law Society of British Columbia, Bencher's Bulletin, No. 5 (November-December 2006), online: The LSBC < http://www.lawsociety.bc.ca/publications_forms/bulletin/2006/06-12-03_prof-dev.html>. Nova Scotia requires members to report any continuing legal education activities, but does not set any targets: Regulations made pursuant to the Legal Professions Act, S.N.S. 2004, c. 28, s. 4.5.1. Introduced as Regulation respecting the mandatory training of notaries concerning the reform of the Civil Code of Québec, R.Q. c. N-2, r. 8.1, made under the Notarial Act, R.S.Q. c. N-2.

64 For a more specific discussion of this issue see Richard Devlin \& Jocelyn Downie, "Fitness For Purpose: Considering Compulsory Legal Ethics" [forthcoming].

65 R. Roy McMurtry, C.J.O., "1999 Report of the Court of Appeal for Ontario” (6 January 1999), online: Court of Appeal for Ontario <http://www.ontariocourts.on.ca/coa/en/ps/ocs/1999.htm>. 
pro bono and publicly-funded legal aid become more important, as do self-help mechanisms for those litigants unable to secure representation of any kind. Fees for legal services lie at the core of the problem, however, and provide a convenient starting point for the discussion.

Allan Hutchinson identifies some of the core complaints about the structure and cost of legal fees.$^{66}$ One of the main targets for complaint is the practice of hourly billing, which Hutchinson argues "can too easily reward inefficiency, incompetence, and even encourages duplicity." ${ }^{167}$ Alternative billing practices such as flat rate billing and contingency fees are becoming more common ${ }^{68}$ and, as Hutchinson notes, there is some suggestion that even a plain hourly fee may not be a reliable indicator of the eventual cost of the services rendered. Other factors may be taken into account in determining a reasonable fee, "including the time and effort involved, special skills required, customary charges of other lawyers in like matters, the amount involved, the results obtained, special circumstances, and the relevant agreement between the lawyer and client. ${ }^{" 69}$ The flexibility of this standard raises important questions about whether even those customers able to afford legal services are getting value for their money.

Thorough guidance and full enforcement by the law societies in relation to billing standards could alleviate many of these concerns. As Hutchinson notes, however, both guidance and enforcement are all too frequently lacking. The codes of ethics in each province require that fees be "fair and reasonable," which seems to target outright dishonesty rather than merely excessive billing. ${ }^{70}$ This seems to be a fairly low hurdle to clear since as both Hutchinson and Gavin MacKenzie note, virtually no one is disciplined for charging unreasonable or excessive fees. ${ }^{71}$

Every client has the option to have his or her bill taxed or reviewed by a court official for fairness. ${ }^{72}$ It should be noted that this is one of the examples of judicial involvement in the regulation of the profession. Moreover, bills which are taxed are overwhelmingly reduced. It is disconcerting that the most effective method of regulating legal fees is the one which removes control from the hands of the profession. If consumers can be guaranteed fair billing only through recourse to the courts, that would seem to be a significant institutional failure of self-regulation.

Allan C. Hutchinson, Legal Ethics and Professional Responsibility, 2d ed. (Toronto: Irwin Law, 2006) at 79-84.

Ibid. at 81 .

Ibid. at 83; see also Alice Woolley, "Evaluating value: a historical case study of the capacity of alternative billing methods to reform unethical hourly billing" (2005) 12 International Journal of the Legal Profession 339, for a review of proposals for a return to older billing practices.

Hutchinson, supra note 66 at 81 .

Ibid. at 82 .

Ibid.; Gavin MacKenzie, Lawyers and Ethics: Professional Responsibility and Discipline, 4th ed. (Toronto: Thomson Carswell, 2006) at 25-13 [MacKenzie, Lawyers and Ethics]. Hutchinson notes that the discipline process is usually only engaged "where there is evidence that the lawyer has actually cheated or duped the client" (supra note 66 at 82 ).

See Woolley, "Time for Change," supra note 55 at 886. 


\section{SELF-REPRESENTED LITIGANTS IN COURT}

Closely related to the problem of rising legal fees and declining access to justice is the increasing number of self-represented litigants in court. While lawyers' fees are rising, funding for legal aid programs has not always kept pace. This disparity means that a growing number of litigants both fail to meet the threshold income to qualify for legal aid and yet cannot practically afford a private lawyer. As many commentators have noted, attempting to represent oneself in court is at best difficult, and in many cases seems virtually hopeless. ${ }^{73}$ While governmental and other public initiatives can be important in reducing the problem, it would seem that the profession has a significant role to play as well.

There are many options available to the profession which have yet to be pursued with any real diligence. First, there is enhanced pro bono involvement, whether on a mandatory basis (which will be dealt with in the next section) or otherwise. Second, there are various options available in relation to legal fees to make particularly straightforward legal services more affordable. For example, some groups have argued for greater emphasis on options like "unbundling" of legal services, whereby a lawyer is retained to perform a single limited task, often for a flat rate, rather than to carry the case through to completion. ${ }^{74}$

Many Canadian codes of ethics include the proviso that "[i]t is in keeping with the best traditions of the legal profession to reduce or waive a fee ... in cases of hardship or impecuniosity." 75 When one considers the complaints about excessive fees, the rates of unrepresented or self-represented litigants in the system, and the general failure of efforts to introduce mandatory pro bono, however, it seems difficult to accept that this is a guiding principle upon which most, or even many, lawyers base their practice. The problems outlined here cannot be ignored forever.

\section{J. Pro Bono}

As set out in the previous three sections, there is an access to justice crisis building in Canada, arising from escalating legal fees and declining funding for legal aid, among other factors. One way to alleviate this crisis without relying on public funding would be through

The old legal adage that "he who represents himself has a fool for a client and an idiot for a lawyer" seems cruel in light of the increasing numbers of less-than-willing self-represented litigants in the courtrooms. Putting the point somewhat more gently, McLachlin C.J.C. stated that "many Canadian men and women find themselves unable, mainly for financial reasons, to access the Canadian justice system. Some of them decide to become their own lawyers. Our courtrooms today are filled with litigants who are not represented by counsel, trying to navigate the sometimes complex demands of law and procedure" (Beverley McLachlin, C.J.C., "The Challenges We Face" (Remarks presented at the Empire Club of Canada, Toronto, 8 March 2007), online: Supreme Court of Canada <http://www.scccsc.gc.ca/aboutcourt/judges/speeches/Challenges_e.asp >).

74 In fact, the LSBC has established a Task Force on the issue of unbundling, which delivered its report to the Benchers in April 2008. The Report was broadly in favour of unbundling as a means of enhancing access to justice, but recommended expanded regulation and ethical guidance for lawyers who attempt to provide unbundled legal services (The Law Society of British Columbia, Report of the Unbundling Legal Services Task Force Limited Retainers: Professionalism and Practice (4 April 2008), online: The LSBC < http://www.lawsociety.bc.ca/publications_forms/report-committees/docs/LimitedRetainers_ 2008.pdf $>$ at 4.

75 See e.g. Nova Scotia, Handbook, supra note 14 at r. 12, cmt. 12.2. 
pro bono service on the part of practising lawyers. Pro bono service can either be given voluntarily or compelled from practitioners as a condition of membership in the profession. Needless to say, the suggestion of the latter never fails to stir controversy and provoke stringent opposition.

Research suggests that voluntary pro bono work on the part of the profession in Canada and the U.S. is both overstated and on the decline. ${ }^{76}$ This realization brings new relevance to proposals to introduce some form of a mandatory pro bono requirement for practitioners. The law societies, however, have been reluctant to make any such move. The Canadian Bar Association (CBA) has made some efforts to review pro bono practice and support enhanced pro bono participation by its members. As Richard Devlin notes, however, these efforts so far "address how to do pro bono work and ensure that pro bono work is done effectively and efficiently rather than why lawyers and firms should undertake pro bono work." ${ }^{77}$ The CBA has so far not required its members to provide any minimum of pro bono service, nor has it offered serious guidelines for the voluntary provision of such services.

Although it is not clearly set out in the ethical codes of each law society, the profession nonetheless arguably has a duty to promote access to justice. A failure of practitioners to recognize and work against the serious problems of access brewing in the Canadian economy is cause for significant concern. If individual practitioners are unwilling or unable to undertake en masse to reverse the present trends and enhance access to justice through vehicles such as pro bono service, then it falls on the profession to encourage or require such action. The failure of the law societies to do so in a meaningful way is not a ringing endorsement of self-regulation.

\section{K. SUMMARY}

Our point in cataloguing these ten examples is not to immediately proclaim "regulatory failure" or suggest that self-regulation is irremediably unsalvageable. Rather, our purpose is to indicate that the current Canadian complacency is unwarranted. At every level of the regulatory regime - establishing standards, monitoring conduct, and enforcing penalties there appears to be serious problems that require us to question whether self-regulation is truly in the public interest.

Moreover, there is one other variable which accentuates our concern that all is not well, and indicates that change may be on the horizon: globalization. As we indicated in the introduction, around the world there has been a widespread rejection of self-regulation as a defensible model of governance. This rejection is not just the work of disgruntled leftist academics bent on rabble rousing. Rather, it is the product of a constellation of forces: governmental priorities, consumer demands, mobilization within the profession itself, and increasingly complex regulatory theory and practice. ${ }^{78}$ This global tsunami against selfregulation is the subject matter of the next section.

76 See Richard Devlin, "Breach of Contract?: The New Economy, Access to Justice and the Ethical Responsibilities of the Legal Profession" (2002) 25 Dal. L.J. 335 at 357.

Ibid. at 359 , n. 132 .

78 See also Seneviratne, Legal Profession, supra note 1, 33-65. 


\section{Comparative DeVelopments: A Global TSUnAMi?}

A look at the regulation of the legal profession throughout common law countries confirms that pure self-regulation has increasingly become an endangered species. It appears, in fact, that Canada may soon be the only country in the Commonwealth where the profession remains self-governing. The type of regulatory intervention and the degree of authority lost by the professional bodies varies among jurisdictions. Some common threads are apparent, however. In most cases, an independent regulatory agency has been created, one which is appointed not by the law society (or its equivalent) but by the government. Frequently the state reclaims responsibility for complaints handling and discipline and assigns it to this body, ${ }^{79}$ but leaves the law society to establish codes of conduct and standards of practice, and even to govern admissions and qualification. Finally, the new mechanisms that are introduced often provide for significant lay participation in the disciplinary process.

The various jurisdictions of Australia and the United Kingdom are leading the charge against self-regulation, with other jurisdictions following close on their heels. In Australia, reforms to the regulation of the profession have been unfolding for more than a decade. Because the legal profession is regulated at the state level, rather than at the federal level, the regulatory structures are not traditionally uniform. Part of the reforms involve an effort to unify the regulatory systems across the country, and to improve the mobility of lawyers. ${ }^{80}$ The reforms are otherwise broadly similar: in most states, the reforms provide for an independent, government-appointed body to handle the complaints and discipline process, usually with some supervised involvement by the Law Society. The Law Society does retain the authority to establish rules and standards for practice, but it is subject to supervision. ${ }^{81}$ Provision is also usually made for significant lay involvement in the regulatory process.

In the U.K., reforms to the governance of solicitors in England and Wales have provided an example which the governments of other jurisdictions have watched with interest. Over the last decade, the Law Society of England and Wales has repeatedly restructured its complaints handling process in response to pressure from government and consumer groups, each time seeking and claiming increased independence for the complaints division from the rest of the Law Society. ${ }^{82}$ The most recent round of reforms, which at the time of writing remain before the British Parliament, would establish a Legal Services Board to oversee the

In many cases, different types of complaints are handled differently, with the independent body taking responsibility for conduct complaints, for example, while the law society retains (though often under supervision) jurisdiction over quality of service complaints, and the courts jurisdiction over civil claims against lawyers.

See Law Council of Australia, Legal Profession - model laws project: Model Bill (Model Provisions), 2d ed., online: Law Council of Australia <http://www.lawcouncil.asn.au/shared/2426989914.pdf $>$.

For example, in New South Wales, the Law Society has the responsibility to establish standards of conduct, but the Office of the Legal Services Commissioner has the authority to review those standards to ensure that they are in the public interest (Steve Mark, "Is State Regulation of the Legal Profession Inevitable?" (Paper presented to the Pacific Rim Conference, Heron Island, 4 October 2003), online: Office of the Legal Services Commissioner <http://www.lawlink.nsw.gov.au/lawlink/olsc/ll_olsc.nsf/ pages/OLSC_heron>.

82 England, Legal Services Ombudsman and Legal Services Complaints Commissioner, "Legal Services Reform - A Perspective" (June 2007), online: Legal Services Commission <http://www.olso.org/ publications/legal_services_reform_2007.asp> at 8 [Legal Services Reform]. 
regulation of legal practitioners throughout England and Wales, and would completely separate the complaints handling process from the jurisdiction of the Law Society. ${ }^{83}$ In addition, the reforms would provide for the provision of legal service under alternative business structures, including both multi-disciplinary practices and larger commercial practices, meaning, for example, that "retailers could offer legal services" (for instance "Tesco law firms"). ${ }^{84}$

Scotland has also passed similar reforms, providing for an independent regulatory agency with substantial lay representation which would take over some authority from the Law Society and Faculty of Advocates. ${ }^{85}$ The new structure involves a split between professional service complaints and low-level negligence complaints on the one hand, and professional misconduct and discipline complaints on the other. The new Scottish Legal Complaints Commission will handle the former independently of the profession, while the Law Society and Faculty of Advocates will continue to handle the latter. ${ }^{86}$ The new body provides for substantial lay participation in the process: it will be chaired by a non-lawyer, with four lawyer and four non-lawyer members. ${ }^{87}$ Details of the structure of the new Commission will be released as its launch target of mid-2008 draws closer. ${ }^{88}$

Reforms are underway in other countries as well: in Ireland, recent reforms have provided for more lay involvement in the professional regulatory bodies, without actually removing regulation from the hands of the profession. ${ }^{89}$ Legislation is presently under consideration which would create the office of the Legal Ombudsman to review the claims of those dissatisfied with the complaints handling processes of the professional bodies. ${ }^{90}$ In New Zealand, reforms have been introduced requiring the Law Society to split its representative and regulatory functions. ${ }^{91}$ These will supplement previous reforms which established the office of the Lay Observer, who has the responsibility for reviewing the handling of complaints by the Law Society. ${ }^{92}$ Finally, in South Africa, the local professional bodies retain

83 Ibid. at 12. The new Legal Service Board would provide for substantial lay representation, including the first chair of the Board (at 14). These reforms rely heavily on the comprehensive report by Sir David Clementi, Review of the Regulatory Framework for Legal Services in England and Wales: Final Report (London: Department for Constitutional Affairs, 2004), online: Legal Services Review <http:// www.legal-services-review.org.uk/content/ report/report-chap.pdf>. Supra note 82 at 12.

The Scottish Government, News Release, "Scottish Legal Complaints Commission" (27 July 2007), online: The Scottish Government News <http://www.scotland.gov.uk/News/Releases/2007/07/ $27101226>$.

Ibid.

Ibid.

Ibid.

The Barrister's Professional Conduct Tribunal now numbers five lay members and four practitioner members; it sits in panels of three, including two lay members and one practitioner member (The Bar Council, "How to make a complaint about a barrister" (January 2007), online: The Law Library of Ireland <http://www.lawlibrary.ie/docs/How_to_make_a_complaint_about_a_barrister/982.htm>). An Tanaiste, (Speech delivered at Regulating the Professions Conference, Ireland, 10 November 2006), online: Department of Justice, Equality, and Law Reform <http://www.justice.ie/en/JELR/Pages/ SP07000416>.

Letter from Chris Darlow to Practitioners (26 April 2006), online: New Zealand Law Society $<$ http://www.nz-lawsoc.org.nz/PDFs/LCA/Letterweb.pdf>.

Ibid. 
powers of self-regulation, but debate continues over reforms to establish a more independent national regulatory body. ${ }^{93}$

Taken together, these international developments portray Canada as increasingly unique in its continued reliance on almost completely unhindered self-regulation for the legal profession. Independent of the specific reasons for concern raised in the last section, it seems either naïve or obtuse to imagine that there is no need even for debate about the issue in Canada. Virtually every other similarly-situated jurisdiction in the world is at least exploring other options, if not already reworking its regulatory regime. In the absence of clear and unequivocal evidence, it is difficult to believe that the Canadian profession is not affected by the same factors motivating reforms in other jurisdictions. On what basis could one sustain the claim that Canadian lawyers are better at regulating themselves than their Australian, British, Scottish or New Zealand counterparts? The next section will identify and consider some of the traditionally proffered justifications.

\section{THE WELL-TILLED FIELd: Arguments Pro and Con Self-Regulation}

The arguments pro and con self-regulation have been developed over many decades, by many authors, in many different fora. ${ }^{94}$ It is therefore unnecessary to rehearse them in detail. However, a brief overview is helpful in order to set the context for the remainder of the article and to highlight the complexity of the problem of designing a suitable regulatory regime. Regulation is not just about techniques and institutions, it is also about the underlying values of the society in which it operates: democracy, accountability, equality, transparency, effectiveness, and efficiency. Consequently, it is incumbent on analysts to both question their taken-for-granted assumptions and avoid overly hasty conclusions.

The essence of the argument in favour of self-regulation can be captured in the formula, $\mathrm{A}+\mathrm{E}=\mathrm{I}$ : autonomy plus expertise $=$ independence from state regulation and market forces. The essence of the critique is the old latin maxim: quis custodiet ipsos custodes, or more polemically: should we allow the fox to guard the chickens - or is it wise to put Dracula in charge of the bloodbank? ${ }^{95}$

These larger propositions can be broken down into a more specific series of claims.

On 29 November 2007, the Law Society of South Africa adopted the Legal Services Sector Charter, which sets a number of reform goals for the Law Society, including notably the creation of a national regulatory body and a legal services ombudsman: Law Society of South Africa, "Legal Services Sector Charter" (4 December 2007), online: Law Society of South Africa <http://www. lssa.org.za/LinkClick.aspx?link=LSC+-+4+DECEMBER+2007.doc\&tabid=53\&mid=412> at 17 . Exhibit Vital Signs?" (1995) 33 Alta. L. Rev. 800; Hurlburt, supra note 1; W. Wesley Pue, "In Pursuit of Better Myth: Lawyers' Histories and Histories of Lawyers” (1995) 33 Alta. L. Rev. 730. The leading Australian and British discussions are Christine Parker, Just Lawyers: Regulation and Access to Justice (Toronto: Oxford University Press, 1999) [Parker, JL]; Seneviratne, Legal Profession, supra note 1. The most helpful American source is David B. Wilkins, “Who Should Regulate Lawyers?”(1992) 105 Harv. L. Rev. 799.

95 See generally Arun Arora \& Andrew Francis, The Rule of Lawyers, Discussion Paper No. 42 (London: Fabian Society, 1998). 


\section{A. Arguments in Favour}

\section{INDEPENDENCE OF THE BAR}

It is often argued that the independence of the bar is an unqualified social good and that, of necessity, such independence requires self-governance. ${ }^{96}$ For example, in Canada (A.G.) v. Law Society of British Columbia, Estey J. argued:

The independence of the Bar from the state in all its pervasive manifestations is one of the hallmarks of a free society. Consequently, regulation of these members of the law profession by the state must, so far as by human ingenuity it can be so designed, be free from state interference, in the political sense, with the delivery of services to the individual citizens in the state, particularly in fields of public and criminal law. The public interest in a free society knows no area more sensitive than the independence, impartiality and availability to the general public of the members of the Bar and through those members, legal advice and services generally. The uniqueness of position of the barrister and solicitor in the community may well have led the province to select self-administration as the mode for administrative control over the supply of legal services throughout the community. ${ }^{97}$

In Pearlman, Iacobucci J. quoted with approval the following extract from a report commissioned by the Attorney General of Ontario:

The regulation of professional practice through the creation and the operation of a licensing system, then, is a matter of public policy: it emanates from the legislature; it involves the creation of valuable rights; and it is directed towards the protection of vulnerable interests.

On the other hand, where the legislature sees fit to delegate some of its authority in these matters of public policy to professional bodies themselves, it must respect the self-governing status of those bodies. Government ought not to prescribe in detail the structures, processes, and policies of professional bodies. The initiative in such matters must rest with the professions themselves, recognizing their particular expertise and sensitivity to the conditions of practice. In brief, professional self-governing bodies must be ultimately accountable to the legislature; but they must have the authority to make, in the first place, the decisions for which they are to be accountable.

Stress was rightly laid on the high value that free societies have placed historically on an independent judiciary, free of political interference and influence on its decisions, and an independent bar, free to represent citizens without fear or favour in the protection of individual rights and civil liberties against incursions from any source, including the state. ${ }^{98}$

G.D. Finlayson, "Self-Government of the Legal Profession - Can it Continue?" (1985) 4 Advocates' Soc. J. 11; Hurlburt, supra note 1 at 170-72, 182; Gavin MacKenzie, "Regulatory Models and Options for the Legal Profession in the 21st Century" at 3-4 [unpublished, on file with authors] [MacKenzie, "Models"]; Arthurs, supra note 94 at 801; Parker, JL, supra note 94 at 135; Pue, supra note 94 at 74251. 
Justice Iacobucci concluded after this quote that: "[o]n this view, the self-governing status of the professions, and of the legal profession in particular, was created in the public interest." 99

These claims are often backed up with reference to international norms, such as the United Nations Basic Principles on the Independence of the Judiciary $(1985)^{100}$ or the United Nations Basic Principles on the Role of Lawyers (1990). ${ }^{101}$

\section{INDEPENDENCE OF THE JUDICIARY}

This argument is a continuation of the previous claim. The bar is the nursery for the judiciary and an independent legal profession helps to foster the independence and impartiality so essential to the judicial role. ${ }^{102}$

\section{DEMOCRACY, FREEDOM, AND THE RULE OF LAW}

Because a free and democratic society requires an independent judiciary to maintain the rule of law, that free and democratic society of necessity also needs an independent legal

Pearlman, ibid. Similarly in Andrews v. Law Society of British Columbia, [1989] 1 S.C.R. 143 at 187, McIntyre J. claimed that "in the absence of an independent legal profession, skilled and qualified to play its part in the administration of justice and the judicial process, the whole legal system would be in a parlous state."

See 3.02 and 3.03, United Nations, Universal Declaration on the Independence of Justice in Shimon Shetreet \& Jules Deschênes, Judicial Independence: The Contemporary Debate (Boston: Martinus Nijhoff, 1985):

3.02 [The] independence [of the legal profession] constitutes an essential guarantee for the promotion and protection of human rights.

3.03 There shall be a fair and equitable system of administration of justice which guarantees the independence of lawyers in the discharge of their professional duties without any restrictions, influences, inducements, pressures, threats or interferences, direct or indirect, from any quarter or for any reason.

Note, however, that 3.03 does not explicitly endorse self-governance; at best it can only be implied.

101 See arts. 24-25, United Nations, Basic Principles on the Role of Lawyers (1990), UN GAOR, 8th Sess., UN Doc. A/CONF.144/28/Rev.1 (1990) at 118:

24. Lawyers shall be entitled to form and join self-governing professional associations to represent their interests, promote their continuing education and training and protect their professional integrity. The executive body of the professional associations shall be elected by its members and shall exercise its functions without external interference.

25. Professional associations of lawyers shall cooperate with Governments to ensure that everyone has effective and equal access to legal services and that lawyers are able, without improper interference, to counsel and assist their clients in accordance with the law and recognized professional standards and ethics.

What is interesting about this is that while art. 24 explicitly favours self-governance - it is to "represent their interest" - not the public interest! Note how this is in tension with art. 25 "everyone has effective and equal access to legal services." It is, however, also important to take note of art. 28:

Disciplinary procedures against lawyers shall be brought before an impartial disciplinary committee established by the legal profession, before an independent statutory authority, or before a court, and shall be subject to an independent judicial review" [emphasis added].

Clearly art. 28 recognizes the legitimacy of forms of regulation beyond self-regulation.

Parker, JL, supra note 94 at 123; Arthurs, supra note 94 at 801; Hurlburt, supra note 1 at 170-71; Pue, supra note 94 at 742-51. See also Roy Millen, "The Independence of the Bar: An Unwritten Constitutional Principle" (2005) 84 Can. Bar Rev. 107 at 118-19, 121, 126. 
profession as a linchpin to secure the public good. ${ }^{103} \mathrm{~W}$. Wesley Pue, for example, has recently argued that there can be an organic relationship between the independence of the legal profession and the emergence of "liberal constitution." 104 The nexus is that an independent legal profession can only exist if it is self-regulating.

\section{Public CONFIDENCE IN THE LEGAL PROFESSION}

Proponents of self-regulation argue that if the general public had the perception that lawyers were subject to the control of the state, then that public would not have the confidence that lawyers will resolutely pursue the interests of their client against the state. ${ }^{105}$ The independence of the legal profession should not only be done, but manifestly and undoubtedly be seen to be done.

\section{TRADITION}

Self-regulation by the legal profession can be traced all the way back to at least the fifteenth century, if not earlier. ${ }^{106}$ For some this means that self-regulation is a fundamental aspect of our legal heritage ${ }^{107}$ and perhaps even an aspect of our unwritten constitution. If self-government were lost, the legal profession would be "a mere trade or business," 108 rather than a pillar of our liberal social order.

\section{EXPERTISE}

This claim proposes that only lawyers have the relevant expertise and knowledge to formulate appropriately nuanced rules and assess the compliance of other lawyers with, or their deviation from, such rules. ${ }^{109}$ For example in Jabour, Estey J. opined that "the nature of the services they [lawyers] bring to the public makes the valuation of those services by the unskilled public difficult" and that "[t]he general public is not in a position to appraise unassisted the need for [or effectiveness of] legal services." "Similarly, in Pearlman the Supreme Court of Canada indicated that only lawyers have the "particular expertise and sensitivity to the conditions of practice" to assess other lawyers. ${ }^{111}$ A more poignant version is Justice Finlayson's proposition that "No one knows better than a fellow lawyer whether or not a brother lawyer has become a transgressor.", 112

103 Wilkins, supra note 94 at 858-63; Pue, supra note 94 at 742-51; Millen, ibid. at 119-20.

104 W. Wesley Pue, "Death Squads and 'Directions over Lunch': A Comparative Review of the Independence of the Bar" in LSUC, Public Interest, supra note 21, 83 at 95 [Pue, "Death Squads"]; MacKenzie, "Models," supra note 96 at 3-4.

Hurlburt, supra note 1 at 183; Millen, supra note 102 at 128; MacKenzie, "Models," ibid. at 17, 46, 54. Parker, JL, supra note 94 at 12; Hurlburt, supra note 1 at 36; Arthurs, supra note 94 at 801; Pue, supra note 94 .

For an excellent compendium and critical analysis of this type of claim see Pue, ibid. at 738-41.

Arthurs, supra note 94 at 801 .

Anthony Ogus, Regulation: Legal Form and Economic Theory (Toronto: Clarendon Press, 1994) at 107; Arthurs, ibid;; Hurlburt, supra note 1 at 173; MacKenzie, "Models," supra note 96 at 40; Seneviratne, Legal Profession, supra note 1 at 27-28.

Jabour, supra note 97 at 334-35.

Pearlman, supra note 1 at 887.

Supra note 96 at 16. 


\section{EFFICIENCY}

This argument is closely connected to the previous argument. The advocates of selfregulation argue that the costs of regulation are internalized to the profession because they are borne by membership through the payment of fees. Consequently, there is no additional bureaucracy that needs to be bankrolled out of the taxes paid by the general public. ${ }^{113}$ Moreover, the cheapest and most efficient way to protect a victimized member of the public is to internalize the cost to the profession via mandatory insurance and reimbursement from liability funds.

\section{HIGHER STANDARDS}

This argument advances the claim that the profession can more finely calibrate the responsibilities of lawyers, and tailor penalties more appropriately, than government regulation, or blunt instruments such as criminal prosecution or civil suits. Moreover, law societies are able to develop complaints resolution procedures that deal with the real and specific concerns of clients without invoking draconian disciplinary processes and they can also deploy other regulatory devices that fulfill the public interest. ${ }^{114}$ In other words, in order to both protect the public and promote its reputation, the profession "funnels in" conduct that would otherwise go unchecked. ${ }^{115}$

\section{COMmitment to The Public Good}

This is essentially a psychological argument: because lawyers recognize that they have been entrusted with a sacred privilege they tend, both as individuals and a group, to contribute to the public good by, for example, seeking to maintain high standards of "professional purity" 116 and moral reasoning among themselves. ${ }^{117}$ Others also suggest that self-regulation encourages lawyers to enhance access to justice through reduced fees for those who are in need, or even participation in pro bono activities. To remove self-regulation would be to undercut this psychological motivation to promote the public good, and alienate the profession from its traditional commitments. ${ }^{118}$

\section{B. Arguments Against}

There are, however, a significant number of arguments that cast doubt on the foregoing claims. The essence of the critique is that self-regulation is a privilege (not a right) that was

113 Parker, JL, supra note 94 at 136; Ogus, supra note 109 at 107; Seneviratne, Legal Profession, supra note 1 at $27-28,137$.

114 Hurlburt, supra note 1 at 113-14, 137-38, 153, 177-80; MacKenzie, "Models," supra note 96 at 18-19, 47-48; Seneviratne, Legal Profession, supra note 1 at 29.

115 Seneviratne, Legal Profession, supra note 1 at 146; Joan Brockman \& Colin McEwen, "Self-Regulation in the Legal Profession: Funnel In, Funnel Out, or Funnel Away?" (1990) 5 C.J.L.S. 1; Joan Brockman, “An Update on Self-Regulation in the Legal Profession (1989-2000): Funnel In and Funnel Out" (2004) 19 C.J.L.S. 55.

116 Hurlburt, supra note 1 at 112, 141-44; Seneviratne, Legal Profession, supra note 1 at 175.

$117 \quad$ Parker, JL, supra note 94 at 134, 151-52; Wilkins, supra note 94 at 863.

118 MacKenzie, "Models," supra note 96 at 17, 38. 
granted to the legal profession as part of a "regulative bargain," 119 and in return, the profession would promote and protect the public interest. ${ }^{120}$ The legal profession, the critics claim, has failed to live up to the regulative bargain on a number of levels.

\section{CONFLICT OF INTEREST}

The key concern of the conflict of interest claim is that it is not possible for a single organization to fulfill both a representative function and a regulatory function. ${ }^{121}$ According to the critics, it is just too convenient that the public interest in accessing legal services should be presumed to dovetail with the professional interest in providing such services. The legal profession prohibits individual lawyers from benefiting from conflicts of interest, but is oblivious to its own constitutive conflict of interest. For example, if one analyzes the sorts of pitches that are made by candidates seeking election to bar council, they overwhelmingly reflect the interests and concerns of lawyers, not the public. ${ }^{122}$

Critics of self-regulation, just like its defenders, also play the public perception card: even if there is no actual conflict of interest and the profession does successfully put the public interest ahead of its own, the public is not likely to see it that way and that perception is just as important as reality. If confidence in the rule of law really is at stake, then it should be beyond doubt that the guardian of the rule of law, the legal profession, must itself be free of the taint of impartiality. ${ }^{123}$

Mary Seneviratne points out that in the English context there were some lawyers who agreed that regulation and representation should be separated for several reasons: first, law societies could then focus on their representative role; second, lawyers would not be burdened with the increasing bureaucratic costs of regulation; third, it would potentially enhance the legitimacy of the profession in the eyes of the public; and fourth, it might lead to more efficient complaints systems in which both lawyers and the public would benefit. ${ }^{124}$

To buttress this criticism, reference is often made to other professions, for example doctors, who have two very distinct organizations, the Canadian Medical Association (representative), the College of Physicians and Surgeons (regulatory). ${ }^{125}$

119 Seneviratne, Legal Profession, supra note 1 at 8-9.

120 See also Law Society of New Brunswick v. Ryan, 2003 SCC 20, [2003] 1 S.C.R. 247 at para. 36, Iacobucci J.

121 Arora \& Francis, supra note 95. See also Mary Seneviratne, "Consumer complaints and the legal profession: making self-regulation work?” (2000) 7:1 International Journal of the Legal Profession 39 at 48 [Seneviratne, "Consumer Complaints"]; Legal Services Reform, supra note 82 at 10, 27-28; MacKenzie, "Models," supra note 96 at 30-36.

$122 \quad$ Pue, "Death Squads," supra note 104 at 107; Mucalov, supra note 2.

123 Arora \& Francis, supra note 95 at 9, 16.

124 Seneviratne, "Consumer Complaints," supra note 121 at 48-49. See also MacKenzie, "Models," supra note 96 at 32. For an enlightening account of how and why the legal profession in Illinois voluntarily surrendered self-governance, see Michael J. Powell, "Professional Divestiture: The Cession of Responsibility for Lawyer Discipline” (1986) 11:1 Am. Bar Found. Res.J. 31. 


\section{MONOPOLY/MARKET CONTROL}

Although this argument is informed by the economic analysis of law, it is worth noting that it is embraced by critics on both the left and right of the political spectrum. ${ }^{126}$ On this view, the legal profession is a "conspiratorial cartel" 127 and self-regulation is anti-competitive because it limits the supply of legal services, thereby artificially inflating prices. Many legal services could be supplied by others, for example paralegals, and there is no empirical evidence to suggest that the removal of self-regulation would either diminish the quality or availability of legal services. ${ }^{128}$ More specifically, comparative empirical research confirms that in many jurisdictions there is a fundamental "lack of a consumer orientation" on the part of the legal profession and, more importantly, that law societies have done little to try to improve this. ${ }^{129}$ Thus, it is argued that competition might well increase both the possibility of lower prices and improve the quality of services. ${ }^{130}$ In short, it engenders competitiveness in quality control. ${ }^{131}$ In the long-run, this should enhance the level of consumer satisfaction. Other analysts go further and suggest that we are witnessing the phenomenon of "regulationfor-competition," whereby regulatory innovation is seen to be a competitive asset in an increasingly globalized world. ${ }^{132}$

\section{INDEPENDENCE: REALLY ... AND FROM WHOM?}

Critics of self-regulation tend to make three broad claims in response to the independence argument: the first calls for analytical clarity; the second suggests a reality check; and the third pleads for historical accuracy.

First, a number of recent studies of the independence of the bar have been very careful to make a distinction between "the independence of the bar" and "self-governance." While most suggest that there may be a relationship between the two, they are all very explicit that "independence" does not necessarily entail "self-governance." 133 Indeed, a Task Force of the LSUC suggests that the "independence of the bar" is best "understood as a right enjoyed by the public and as a mechanism for maintaining and defending the rule of law." "134 Patrick J. Monahan, for example, argues that the independence at stake is independence from the executive branch of government and that this can be achieved by means other than self-

See generally, Robert G. Evans \& Michael J. Trebilcock, Lawyers and the Consumer Interest: Regulating the Market for Legal Services (Toronto: Butterworths, 1982); Richard L. Abel, The Legal Profession in England and Wales (Oxford: Blackwell, 1988); Pue, "Death Squads," supra note 104 at 89; Seneviratne, Legal Profession, supra note 1 at 14-15, 28-29.

Parker, JL, supra note 94 at 109-112.

Herbert M. Kritzer, "Rethinking barriers to legal practice" (1997-1998) 81 Judicature 100.

Parker, JL, supra note 94 at 12-17. For an example of professional resistance to consumerist claims, see Hurlburt, supra note 1 at $112,114$.

Parker, JL, ibid. at 155 .

Ogus, supra note 109 at 110 ; Parker, $J L, i b i d$. at 158.

David Levi-Faur, "The Diffusion of Regulation and the Diffusion of Capitalism" in McConkey \& Dutil, supra note 1,11 at 13 .

See e.g. Patrick J. Monahan, "The Independence of the Bar as a Constitutional Principle in Canada" in LSUC, Public Interest, supra note 21, 17 at 136; Millen, supra note 102 at 111, n. 29; LSUC, "Protecting the Public through an Independent Bar: The Task Force Report" in LSUC, Public Interest, supra note 21, 3 at 7 [LSUC, "Task Force"].

LSUC, "Task Force," ibid. at 37. 
regulation. ${ }^{135}$ He claims that self-regulation is simply a policy choice in pursuit of the public interest and that other regulatory instruments in pursuit of that interest might be constitutionally legitimate. To buttress this claim, Monahan also invokes Jabour to highlight various dicta of Estey J. that are not usually mentioned by the defenders of self-regulation:

\begin{abstract}
The general public is not in a position to appraise unassisted the need for legal services or the effectiveness of the services provided in the client's cause by the practitioner, and therefore stands in need of protection. It is the establishment of this protection that is the primary purpose of the Legal Professions Act. Different views may be held as to the effectiveness of the mode selected by the Legislature, but none of the parties here challenged the right of the province to enact the legislation. It is up to the Legislature to determine the administrative technique to be employed in the execution of the policy of its statutes. I see nothing in law pathological about the selection by the provincial Legislature here of an administrative agency drawn from the sector of the community to be regulated. Such a system offers some immediate advantages such as familiarity of the regulator with the field, expertise in the subject of the services in question, low cost to the taxpayer as the administrative agency must, by the statute, recover its own expenses without access to the tax revenues of the Province. On the other hand, to set out something of the other side of the coin, there is the problem of conflict of interest, an orientation favourable to the regulated, and the closed shop atmosphere. In some provinces some lay Benchers are appointed by the provincial governments; in other provinces the Attorney General is seized with the duty as an ex officio Bencher of safeguarding the public interest; a right of appeal from decision[s] affecting members is given to the Court; and the confirmation by the Provincial Executive, the Lieutenant Governor in Council, of all regulations adopted by the Society as a prerequisite to their validity. It is for the Legislature to weigh and determine all these matters and I see no constitutional consequences necessarily flowing from the regulatory mode adopted by the province in legislation validly enacted within its sovereign sphere as is the case here. ${ }^{136}$
\end{abstract}

The uniqueness of position of the barrister and solicitor in the community may well have led the province to select self-administration as the mode of administrative control over the supply of legal services throughout the community. Having said all that, it must be remembered that the assignment of administrative control to the field of self-administration by the profession is subject to such important protective restraints as the taxation officer, the appeal to the courts from action by the Benchers, the presence of the Attorney General as an ex officio member of the Benchers and the legislative need of some or all of the authority granted to the Law Society. In any case this decision is for the province to make. ${ }^{137}$

In short, to confuse independence of the legal profession with self-regulation is a subtle, but indefensible legerdemain.

Second, critics call for a reality check. Traditional arguments for independence focus on the threat of the state, but in the modern world the state is not the only, or even major, centre of power and control in society. Corporations also wield great influence. Not only are inhouse counsel especially vulnerable to their economic masters, so too are law firms that service corporations, especially corporations who are repeat clients - he who pays the piper - as the aphorism goes. The independence of the legal profession, in other words, is more apparent than real. 
Third, from a historical perspective, critics point out that the legal profession has been somewhat less than enthusiastic in its pursuit of independence than it is often asserted. ${ }^{138}$ Many of the elements of self-regulation cannot be traced back to the mystical origins of the common law, but are relatively recent, that is twentieth century, developments. ${ }^{139}$ Furthermore, at times the profession has been aligned with repressive forces as much as with democracy and the rule of law. ${ }^{140}$ During the Winnipeg General Strike, some members of the legal profession engaged in outrageous behaviour. ${ }^{141}$ In Quebec during the Duplessis regime, many lawyers refused to provide legal services to Mr. Roncarelli, a Jehovah's Witness, to fight the padlock laws. ${ }^{142}$ Many lawyers did little to protest the invocation of the War Measures Act and, currently, there are allegations that a significant number of marquee criminal defence lawyers made themselves scarce when the Toronto 17 were arrested. And then again, there is Finney who only got pro bono assistance when the case went to the Supreme Court of Canada. As to the argument that there is a threat to the independence of the judiciary, it has been noted that a significant number of judges come from government or universities, yet there is nothing to indicate that they are less independent or impartial. ${ }^{143}$

\section{UNDEMOCRATIC}

In response to the claim that self-regulation is essential for democracy, critics point out that the causal connection is missing: there are many liberal democratic societies where there is no self-government by the legal profession, yet they seem to be flourishing as well as Canada. ${ }^{144}$ Conversely, there are jurisdictions that have a self-regulating legal profession, but are deeply authoritarian, for example, Singapore. Moreover, critics insist that the demand for self-regulation comes from the profession itself, not the general public and as such is, in fact, an exercise in "regulatory imperialism." 145 The concern that the public will lose confidence in the legal profession if self-regulation is abolished is conjecture, devoid of any empirical support. To the contrary, at least one commentator suggests that self-regulation may be only a contingent and transitional moment in the development of a profession as it seeks to establish its legitimacy, but once that legitimacy has been consolidated, self-regulation can be relinquished as the profession becomes more mature. ${ }^{146}$ Moreover, it is argued that the governors within the legal profession are rarely representative of a cross-section of an increasingly diversified and fragmented profession, let alone society. ${ }^{147}$ Given this, it is difficult to imagine how their conception of the public interest could authentically and democratically capture the (increasingly complex) reality of the public interest.

See e.g. Philip Girard, "The Independence of the Bar in Historical Perspective: Comforting Myths, Troubling Realities" in LSUC, Public Interest, supra note 21, 45.

Seneviratne, Legal Profession, supra note 1 at 18.

Girard, supra note 138 at 75-77; Arthurs, supra note 94 at 801; Wilkins, supra note 94 at 861; Pue, supra note 94 at $762-63$.

Girard, ibid.

LSUC, "Task Force," supra note 133 at 4-5.

Arthurs, supra note 94 at 801.

Ibid.

Powell, supra note 124 at 32 .

Ibid. at 52-54.

See also Hurlburt, supra note 1 at 190. 


\section{PROTECTION RACKET}

There are a couple of dimensions to this concern. The first is that despite the fact that codes of conduct both allow and demand whistle-blowing on fellow lawyers, it is very rare for lawyers to report the misconduct of other lawyers. So, while it is true that lawyers may have the expertise to distinguish between proper and improper conduct, that does nothing to ensure that they will in fact exercise that expertise in the public interest. ${ }^{148}$ It is not just high profile cases such as the Pilzmaker case where there is a failure to report; ${ }^{149}$ just speak to members of the profession after a successful discipline prosecution and many will tell you "sure, everybody knew he was a bad apple but...."

Moreover, critics also argue that when discipline proceedings are instituted, the penalties are too lenient because lawyers are too sensitive to their colleague's situation - "there but for the grace of God go I."150 The previous discussion of Hunter is but one example of this. Another concern is that few lawyers are ever disciplined for excessive billing, a common practice that is the most significant complaint from clients. ${ }^{151}$

Still others argue that the complaints processes run by law societies are not especially consumer friendly. ${ }^{152}$ Furthermore, even if people do pursue their concerns, the disciplinary system occupies the field, crowding out other remedial avenues (civil or criminal). The consequence is that discipline is a sop; it funnels complaints away and often miscreant lawyers get off the hook, or receive only minimal discipline. ${ }^{153}$

\section{REACTIVE AND INEFFICIENT INSTITUTIONAL CULTURE}

Because the self-regulatory process is beholden to the lawyers themselves in the form of fees, law societies are significantly underfunded and understaffed. Consequently, they operate reactively, primarily on the basis of complaints, rather than actively seeking out problematic behaviour before it is too late. While law societies are empowered to conduct spot audits and can commence an investigation without a complaint, these actions are the exception rather than the rule.

From a slightly different perspective, it might also be suggested that the regulatory structures of law societies are inefficient or suboptimal. ${ }^{154}$ While it is true that the costs are internalized to the profession, some of our informants indicated that the bureaucracies created

Arthurs, supra note 94 at 801,803 .

See e.g. MacKenzie, "Models," supra note 96 at 27-1.

Seneviratne, Legal Profession, supra note 1 at 124-25, 131-32, 140. MacKenzie notes that in the Lang Michener case, five partners who were members of the executive who failed to make timely disclosure of Pilzmaker's conduct only received a reprimand, supra note 96 at 27-1. Another variation of this concern is when highly respected lawyers appear on behalf of their miscreant colleagues in discipline proceedings to wax eloquent about their good character and how the egregious behaviour is out of character. See Jocelyn Downie \& Richard Devlin, “Are Law Schools Amoral Boot Camps?”, Book Review of Lawyers Gone Bad by Philip Slayton, (2008) 16:1 Literary Review of Canada 6.

Woolley, "Time for Change," supra note 55.

Seneviratne, Legal Profession, supra note 1,137-74.

See e.g. Brockman \& McEwen, supra note 115.

See especially Wilkins, supra note 94; Seneviratne, Legal Profession, supra note 1 at 144. 
by law societies may not be particularly efficient. The argument is that they are run by lawyers, not professional regulators, and consequently they do not get the best bang for the regulatory buck. ${ }^{155} \mathrm{An}$ independent regulatory body can provide greater professionalism, rationality, accessibility, and efficiency. ${ }^{156}$

\section{Psychological CRitiQue}

Some critics also claim that self-governance is not just about enhancing the economic monopoly of lawyers, but also to "bid up the value of their intellectual and cultural capital." ${ }^{157}$ The goal is to enhance the psychic esteem of the legal profession.

\section{PUblic ReLATIONS EXERCISE}

Finally, critics also argue that self-governance is essentially a public relations exercise: it is symbolic and ideological and creates the appearance of responsibility and accountability but not the reality. ${ }^{158}$ Harry W. Arthurs takes this claim one step further by claiming that "regulation is not a major determinant of professional conduct... Professional conduct is ... shaped by three important factors - the personal characteristics of the lawyer, the professional circumstances of his or her practice and the ethical economy of the profession." 159

\section{SYNOPSIS}

This section has demonstrated that advocates and critics of self-regulation of the legal profession have deployed an impressive array of arguments in support of their respective positions. There are, however, two major problems with the debate. First, many of the claims advanced by both sides are asserted at the level of generality. At bottom, many are empirical claims, yet the protagonists rarely provide supporting data. Lawyers, as a profession, put a great deal of emphasis on evidence yet remarkably, there is very little empirical Canadian evidence adduced by either side. As a consequence we are left with rhetoric and bluster. We will return to this point in our conclusion. The second major problem with the debate, in our opinion, is that it has engendered manicheism: in the eyes of the defenders of self-regulation, one is either loyal to the profession or a traitor; in the eyes of the skeptics, one is either a democrat or a dupe. In this article we refuse to be press-ganged into the ideology of "either you are with us or against us." As we will argue in the next section, regulation is a complex phenomenon both conceptually and pragmatically. Moreover, the ethical and political stakes are high. In our opinion, sober consideration indicates that there are elements of truth on both

Wilkins points out the complexity of cost-benefit analysis by emphasizing the important differences between administrative, participant and third party costs (Wilkins, supra note 94 at 820-21). when he recently complained that " $[t]$ he figures on how many of us [benchers of the Law Society of Upper Canada] that refuse to take part in hearings is appalling" and "many of us in the last term have done no discipline work and a large number have done less than they should. The burden is unfairly on the shoulders of a small number" (John Jaffey, "Law Society of Upper Canada allows non-benchers on disciplinary panels" Lawyers Weekly 27:2 (11 May 2007) (QL)). 
sides of the debate. The challenge is to open up the dialogue, to abandon entrenched ideologies, and to enlarge the regulatory imagination of the Canadian legal profession.

\section{ENLARGING THE REGULATORY IMAGINATION: CALIBRATED REgulation AND ITS OPTIONS}

Analysts frequently note that regulation of the professions is a complex and multifaceted process, covering at least three distinct aspects: admission to the profession, the establishment of ethical and quality standards, and discipline for breach of such standards. ${ }^{160}$ The contemporary theory and practice of regulation in many professions in many jurisdictions now recognizes that effective regulation must be able to identify and respond to such complexities. Within the literature, this is variously described as "the new regulatory state,"161 "smart regulation,"162 "decentred regulation,"163 "dynamic regulation,"164 "responsive regulation,"165 "reflexive regulation,"166 "nimble regulation,"167 "metaregulation," "168 "regulatory pluralism,"169 or "the regulatory web."

While there are many significant differences between these various conceptions of regulation, they all agree on three key points: pure self-regulation is both normatively indefensible in a liberal democratic society and strategically ineffective in achieving its goals; the traditional alternative, that is the conventional state-centred command and control model of regulation, is much too blunt an instrument to effectively and efficiently get results $;{ }^{171}$ the only viable strategy is to develop a hybrid and nuanced constellation of civil

160 Pearlman, supra note 1.

161 Giandomenico Majone, "The Rise of the Regulatory State in Europe" (1994) 17:3 West European Politics 77; McConkey \& Dutil, Introduction, supra note 1 at 2.

162 Neil Gunningham \& Peter Grabosky with Darren Sinclair, Smart Regulation: Designing Environmental Policy (Toronto: Clarendon Press, 1998).

163 Black, supra note 1 at 3-8; Julia Black "Decentring Regulation: Understanding the Role of Regulation and Self-Regulation in a 'Post-Regulatory' World” (2001) 54 Curr. Legal Probs. 103.

$164 \quad$ Parker, JL, supra note 94 at 6.

165 Ian Ayres \& John Braithwaite, Responsive Regulation: Transcending the Deregulation Debate (Toronto: Oxford University Press, 1992); Hugh Collins, Regulating Contracts (Toronto: Oxford University Press, 1999) at 67; Parker, JL, ibid. at 140.

166 Collins, ibid. at 358.

167 McConkey \& Dutil, Introduction, supra note 1 at 10.

168 See e.g. Christine Parker, The Open Corporation: Effective Self-Regulation and Democracy (New York: Cambridge University Press, 2002), 245-91 [Parker, OC]; Peter N. Grabosky, "Using Non-Governmental Resources to Foster Regulatory Compliance" (1995) 8 Governance 527 at 543. Other useful ways to think about these forms of regulation are to discuss them as "nodes and networks" (John Braithwaite \& Christine Parker, "Conclusion" in Parker et al., RL, supra note 1, 269 at 277) or "heterarchical" rather than hierarchical" regulation. See e.g. Colin Scott, "Regulating Constitutions" in Parker et al., RL, supra note 1,226 at 227.

169 Braithwaite \& Parker, ibid. at 270-73; Parker, OC, supra note 168 at 131.

170 Braithwaite \& Parker, ibid. at 273-79.

171 Black, supra note 1 at 3, provides the following synthesis of the debate:

$[\mathrm{T}]$ hat the instruments used (laws backed by sanctions) are inappropriate and unsophisticated (instrument failure), that government has insufficient knowledge to be able to identify the causes of problems, to design solutions that are appropriate, and to identify non-compliance (information and knowledge failure), that implementation of the regulation is inadequate (implementation failure), and that those being regulated are insufficiently inclined to comply, and those doing the regulating are insufficiently motivated to regulat $[\mathrm{e}]$ in the public interest (motivation failure and capture theory). 
society/market/state-based regulatory instruments that can be synergistically deployed (in an increasingly intensified way from co-operation to coercion) in a contextually sensitive manner. For the purposes of this article, we will call this "calibrated regulation." 172 One common metaphor is that there should be a "pyramid of regulatory controls." 173 Another is that the state should "steer" rather than "row."

If one stands back and looks at the various regulatory functions relevant to the legal profession, it becomes apparent that "calibrated regulation" is indeed an apt characterization of the beast. William Hurlburt, for example, has provided a very helpful cartography of 17 various and complex regulatory devices that might be used by the legal profession (see Hurlburt's Cartography, below). ${ }^{175}$

Hurlburt argued in 2000 that all of these functions can be fulfilled by self-regulation. However, as we have indicated in Part II of this article, Rumblings in the Peaceable Kingdom, such optimism may no longer be valid in Canada because there have been significant (perhaps even systemic) failures in establishing standards, monitoring behaviour, and enforcement. In the remainder of this section, we will attempt to expand the Canadian regulatory imagination by offering four regulatory models each of which attempts to respond to the reality of "calibrated regulation." In each case, a simplified chart is included as an illustration of the structure described.

Parker, $O C$, provides the following additional helpful synopsis of the alleged weaknesses of the command and control model (supra note 168 at 8 ):

- a tendency towards unnecessarily complex rules that are too difficult or costly for business to access, understand and comply with;

- over-regulation, legalism, inflexibility and unreasonableness in design and implementation that tend to break down the natural willingness to comply with reasonable, substantive objectives;

- evasion and 'creative' compliance by taking advantage of technical and detailed rules, rather than compliance with the substance and goals of regulation;

- 'capture' of regulatory agencies by regulated entities;

- dependence on strong monitoring and enforcement where sufficient resources, expertise and strategy are not necessarily available.

See also Wilkins, supra note 94 at $814-19,851,873$, advocating that, in light of the fact that there several types of lawyer client-interactions and differences in enforcement contexts, then it is essential to have multiple centres of professional control, a "multi-door enforcement system" (at 873).

Supra note 162; Parker, JL, supra note 94 at 147, 162-67.

David Osborne \& Ted Gaebler, Reinventing Government: How the Entrepreneurial Spirit is Transforming the Public Sector (Reading, Mass.: Addison-Wesley, 1992) at 25; McConkey \& Dutil, eds., "Introduction," supra note 1 at 1.

Hurlburt, supra note 1 at 67-68. 


\section{Hurlburt's Cartography}

The devices employed by the law societies to promote the competence and ethical motivation of lawyers (the uplift side) are as follows:

1. Influence on or control of the pre-legal and legal education of incoming lawyers.

2. Apprenticeship or supervision (articling, pupillage, and training contracts).

3. Vocational training (vocational courses, bar admission courses, and bar admission examinations).

4. Requirements of good character.

5. Promulgation and promotion of ethical standards (general).

6. Promulgation and promotion of ethical standards (duty of competence).

7. Practice advisory services.

8. Certification of specialists.

9. Encouragement of continuing legal education or the establishment of mandatory continuing legal education.

The devices on the policing and punishment side are as follows:

1. Discipline and sanctions (general).

2. Discipline and sanctions (competence).

Devices which have both uplift and policing aspects and which therefore occupy a middle ground between the promotion of standards, on the one hand, and discipline and sanctions, on the other, are as follows:

1. Practice review.

2. Remedial continuing legal education.

3. Supervision.

4. Restrictions on practice.

A fourth element, devices which do not directly affect professional standards but which are part of a system for the protection of the public, are as follows:

1. Schemes for the compensation of clients for dishonesty and misappropriation of funds.

2. Schemes for the compensation of clients for negligent or incompetent service.

If the traditional model of self-regulation places full regulatory authority over all of Hurlburt's factors in the hands of the law societies [as represented in Figure 1], then the models of calibrated regulation described here all involve the splitting of such authority along one or more lines. Where self-regulation grants law societies unfettered and unsupervised regulatory authority, these models involve other agents in the process, narrow the authority of the law societies, and strip them of responsibility over some functions. None of these models envisions the total removal of the law societies from the process. Each recognizes that the expertise and experience of the profession in regulating itself is not to be disposed of lightly, and seeks a workable and effective compromise in the division of authority. It is worth noting also that these models represent points on a continuum and not watertight compartments. They are not presented as mutually exclusive, but rather as broadly overlapping illustrations of a few recurring categories of regulatory reform. 


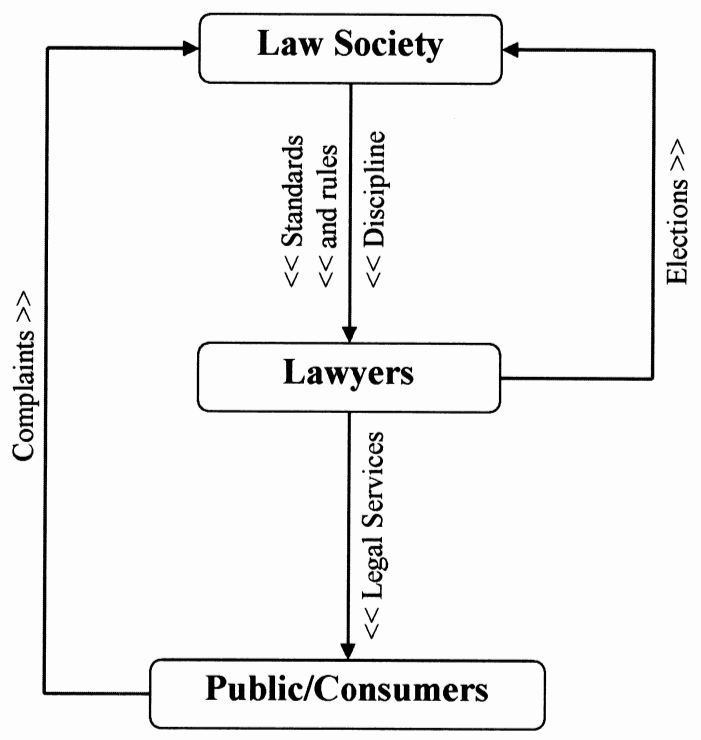

Figure 1: Prototypical Model of Self Regulation

The first, and perhaps most straightforward of these reforms splits the regulation of the profession along the rule creation/rule enforcement line [See Figure 2]. Under this model, the responsibility for rule-creation, or the first nine 'uplift' factors of Hurlburt's list, remains in the hands of the Law Society. The Law Society sets standards of ethical behaviour and competence, it governs the rules for admission and stipulates the pre-admission educational requirements, it sets the program of articling or apprenticeship and any professional training, including bar courses and exams. The rule enforcement side of regulation, or Hurlburt's policing and punishment, is removed from the hands of the Law Society. An independent body is created with the responsibility of hearing and determining complaints against practising lawyers, and for administering discipline.

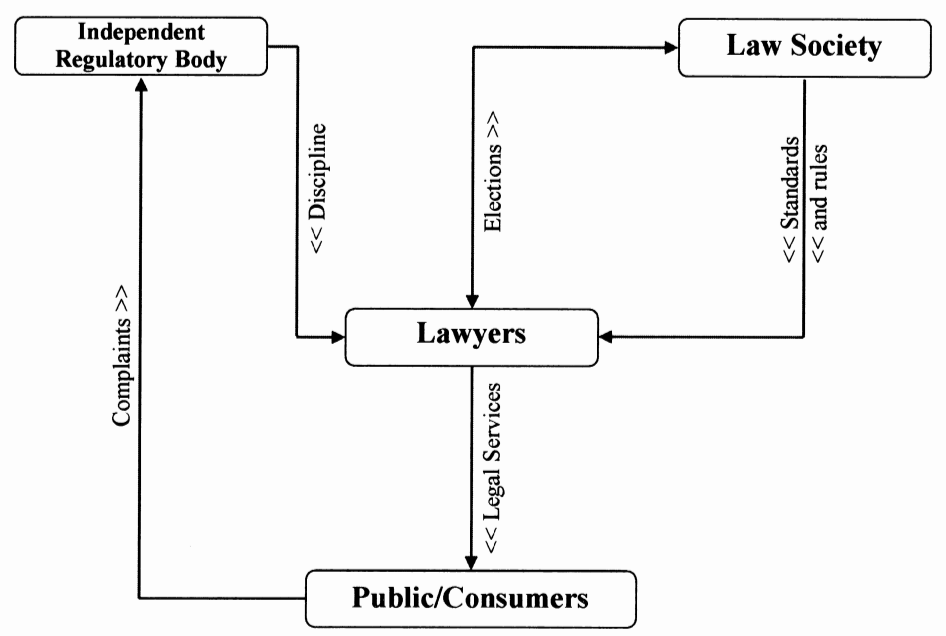

Figure 2: Coregulatory Option 1: Authority split between rule-making and rule-enforcement 
Looking to reforms in other parts of the world (as briefly outlined above in Part III, above), this fairly basic change to the structure of professional regulation is common. In England and Wales, pending reforms will take responsibility for complaints and discipline away from the Law Society, while also introducing more comprehensive oversight and more effective lay participation into the system, ${ }^{176}$ two changes which we will consider shortly. The reforms recently completed or underway in most Australian states are similar. The states of New South Wales, Queensland, and Victoria all provide for an independent body to administer complaints against lawyers, while the Law Society retains varying degrees of authority to set the standards of practice and ethical rules against which those lawyers will be judged. ${ }^{177}$

The problem of a conflict of interest - real or perceived - is at the heart of this reform, and in a large measure is why it is so common. Whether accurate or not, there is an appearance of a conflict of interest in lawyers judging their own for compliance with ethical and competency standards they have set. Transferring the judging function to another body eliminates this conflict. This particular division has the additional advantage of allowing law societies to continue to set rules and standards of practice, a task which arguably requires a great deal of experience with the practice of law and its ethical potholes and deadfalls. Some argue, however, that allowing the profession to retain this function is not enough. ${ }^{178}$ They claim that this same experience is a necessary prerequisite to determining whether lawyers have complied with the ethical standards, or demonstrated an appropriate level of competence. The following co-regulatory compromise in some measure addresses this claim.

A second common type of co-regulatory reform is to split the disciplinary process itself [See Figure 3]. Leaving Hulburt's "uplift" factors aside for the moment, reforms of this sort divide the disciplinary and complaints process in some way; for example, (1) conduct complaints alleging breaches of ethical standards, and (2) competence complaints alleging poor quality of service [as in Figure 3]. An independent body such as that described above takes over responsibility for one genre of complaints, while the Law Society retains jurisdiction to deal with the other.

See Legal Services Reform, supra note 82 and text.

See supra note 81 .

See Part IV, above, for a full exposition of the various arguments for and against self-regulation. 


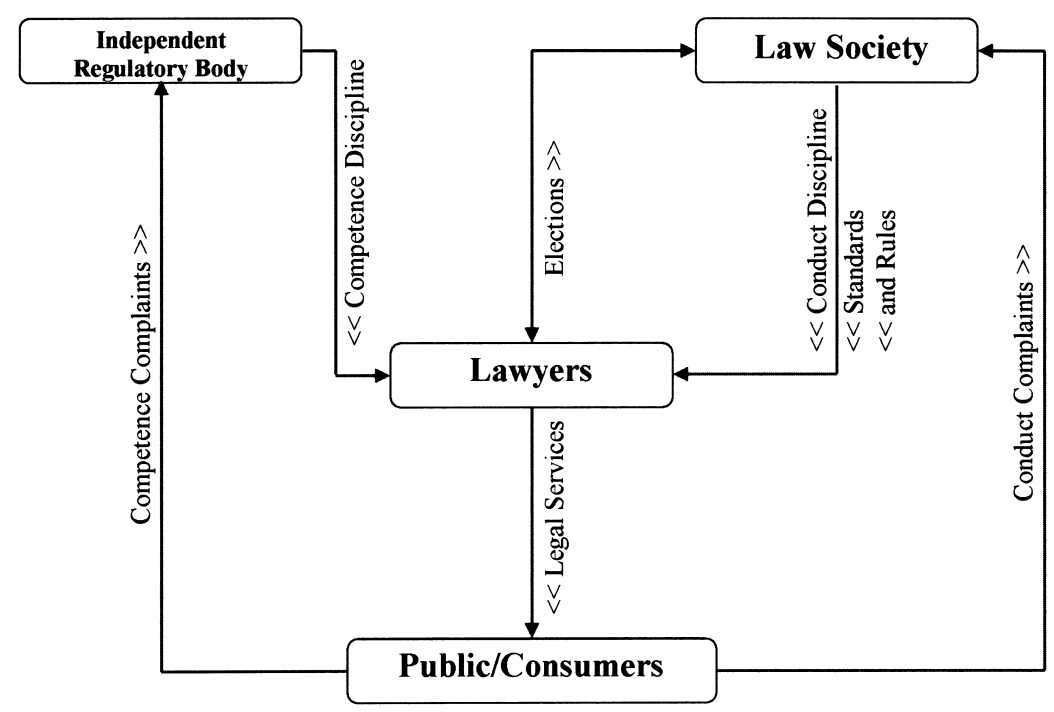

Figure 3: Coregulatory Option 2: Authority split by category or discipline

This structure should be familiar to Canadian practitioners. All Canadian jurisdictions already provide for some division in complaints, even while remaining wholly selfgoverning. We are referring, of course, to the jurisdiction of the courts over civil complaints, including both fee disputes and professional negligence claims. ${ }^{179}$ Internationally, several jurisdictions distinguish between competence and conduct complaints in their reformed discipline process. In Scotland, the forthcoming reforms distinguish between the two, leaving conduct issues to the Law Society to deal with, while the Scottish Legal Compliants Commission will hear claims of incompetence and poor service. ${ }^{180}$ In New South Wales, a distinction is drawn between three types of complaints: consumer disputes, unsatisfactory professional conduct complaints, and misconduct complaints. ${ }^{181}$ In all cases, as discussed above, complaints are brought initially to the Office of the Legal Services Commissioner, who has the authority to remit the complaint back to the Law Society for resolution. The category of complaint determines the scope of the Law Society's authority. ${ }^{182}$

The next two regulatory options are essentially two ends of the same spectrum. The first model can be described as oversight regulation. It is common to many of the reforms underway internationally and, in fact, it frequently predates the most recent round of reforms. It seems to be a common first step in reforming professional regulation. Rather than

179 Many professional negligence claims could even be conceived of as a sort of extreme competence issue. When viewed in this way, the division of authority between competence and conduct complaints seems even less radical.

$180 \quad$ See supra note 90.

181 Law Society of New South Wales, "What You Need to Know About Practising Under the Legal Profession Act 2004 (LPA) and Legal Profession Regulation 2005 (LPR)," online: Law Society of New South Wales <http://www.lawsociety.com.au/page.asp?PartID=17419>. 
withdrawing authority from the Law Society, this model places a check on that authority through the creation of an independent body to oversee the operation of some or all of the Society's regulatory functions [See Figure 4]. While the body is frequently at least partly made up of lay persons, its precise composition and extent of its powers of review over the actions of the Law Society varies by jurisdiction. Most commonly, the body provides some protection for complainants dissatisfied with the operation of the Law Society's complaints handling process. This may be through a formal review and reconsideration of individual decisions, or through general monitoring and operational review. ${ }^{183}$ The body may be empowered to overturn decisions of the Law Society, or only to request that it review and reconsider a particular matter. ${ }^{184}$ Furthermore, the oversight body may hear complaints directly from consumers in certain circumstances, for example, where the complaint is with regards to the Law Society's discipline processes, or where it implicates the Law Society itself.

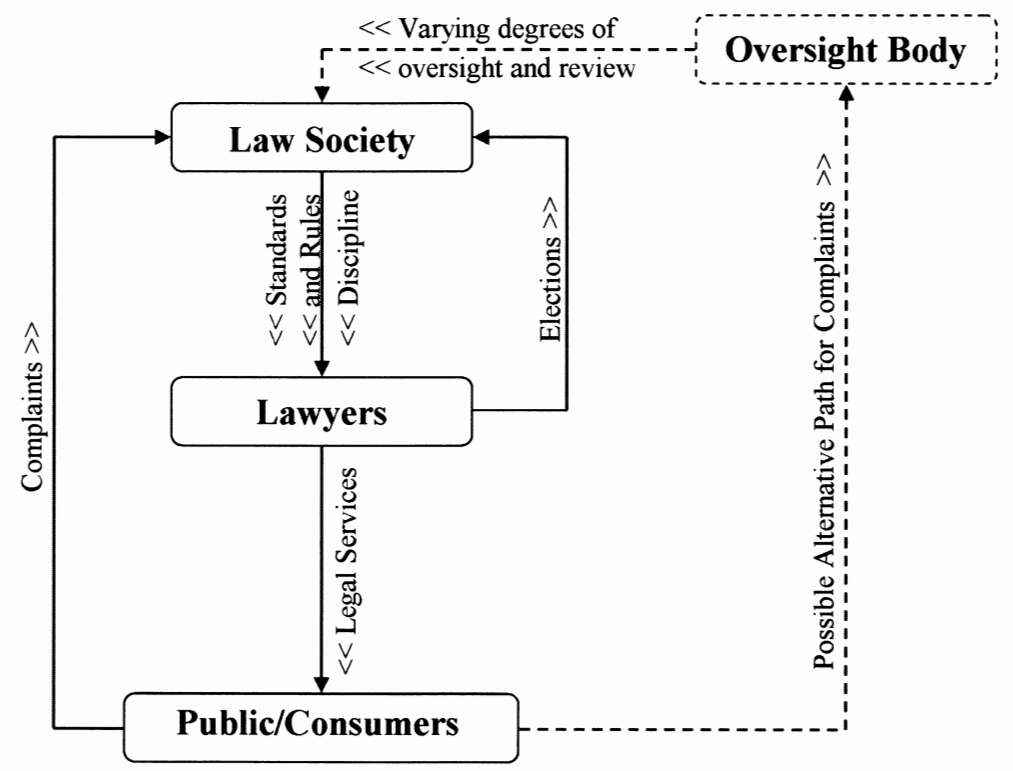

Figure 4: Coregulatory Option 3: Oversight Regulation

This model has been introduced in one form or another in virtually all of the jurisdictions reviewed in Part III, above. The long process of reform in England and Wales has involved several forms of oversight body, culminating in the forthcoming Legal Services Board, which shades from oversight into full independent regulation, a topic which will be addressed shortly. ${ }^{185}$ In all of the Australian states which have instituted some reforms to the governance of the profession, some form of strong oversight body has been created,

183 Commentators sometimes characterize this distinction as "fire-fighting" (complaints handling) or "firewatching" (detecting defects in bureaucratic systems). See e.g. Seneviratne, Legal Profession, supra note 1, 179-209. Others also ask whether its role should be a reactive complaints-based approach or more aggressive and interventionist. Wilkins, supra note 94 at 844-47.

185 Legal Services Reform, supra note 82. 
including notably New South Wales. ${ }^{186}$ Even in New Zealand, where reforms to professional regulation have been relatively restrained, the Complaints Review Office has been created, with the jurisdiction to hear complainants dissatisfied with the Law Society's handling of their case, and to bring disciplinary prosecutions itself where it sees fit. ${ }^{187}$

There are no guarantees that oversight bodies will work perfectly. For example, Quebec is alone in Canada in having an Office of the Professions which has both regulatory and research capacity over the professions, including law, ${ }^{188}$ and yet this failed to prevent the Finney case. ${ }^{189}$ Similarly, in England and Wales, a series of different oversight bodies have failed to satisfy both consumers and regulators. ${ }^{190}$ None of the regulatory options presented here is in fact offered as a definitive answer to the criticisms of the present system. Each branch of reform has its own particular strengths and weaknesses, which together warrant a full and frank discussion of the available options.

Where oversight shades into the withdrawal of actual power or ultimate decision-making authority from the Law Society, the structure may more appropriately be called one of full independent regulation. The move to fuller models of independent regulation seems to have arisen in some jurisdictions out of dissatisfaction with the effectiveness of oversight regulation. ${ }^{191}$ Under a model of independent regulation, all regulatory authority is withdrawn from the Law Society and assigned to an independent appointed regulatory agency [See Figure 5]. In many cases, the Law Society will not be cut out completely of the regulatory process: the independent regulator may delegate some authority back to the Law Society to act as a front line regulator, for example, receiving complaints at first instance, or drafting codes of ethics and standards of practice. This is a very limited form of co-regulation. The regulatory body retains the power to withdraw what authority it delegates should it see fit. This may be by requiring the Law Society to hand over investigation or prosecution of a complaint, or by amending the rules of practice on its own motion, for example.

In New South Wales, the independent body is the Office of the Legal Services Commissioner (online: Lawlink of New South Wales <http://www.lawlink.nsw.gov.au/lawlink/olsc/ll_olsc.nsf/pages/OLSC_ index $>$ ); see also Parker, $J L$, supra note 94 at 163. In Victoria, the body is the Legal Services Board (online: Legal Services Board <http://www.lsb.vic.gov.au>). In Queensland, it is the Legal Services Commission (online: Queensland Law Society <http://www.qls.com.au>). 


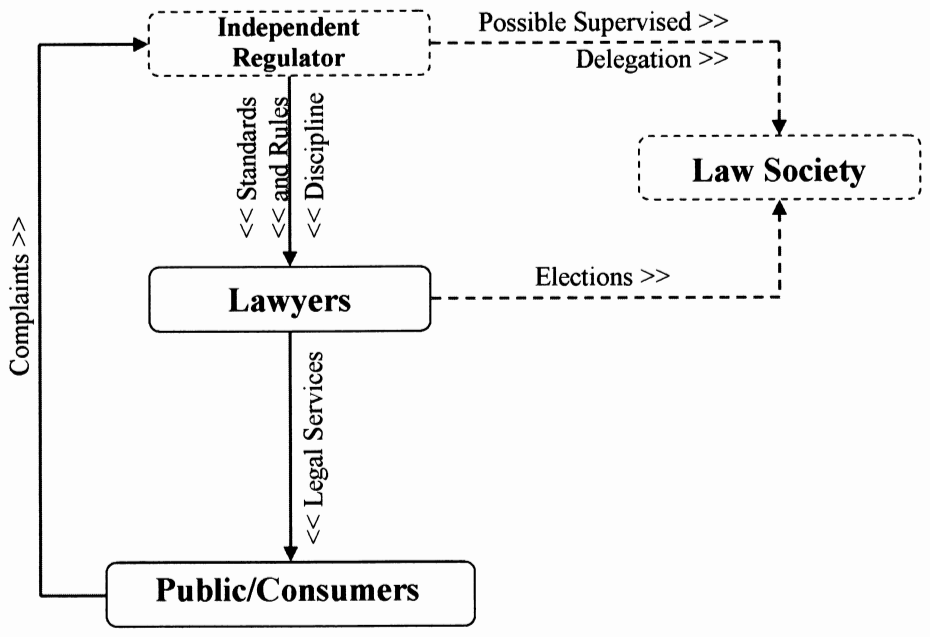

Figure 5: Prototypical Independent Regulation

A number of countries have introduced reforms which will take their regulatory regimes closer to an independent model. ${ }^{192}$ The closest regulatory system presently operating, however, is that in the Australian state of Victoria. As mentioned above, many Australian states incorporate elements of oversight into their regulatory structures. In Victoria, the government has taken oversight one step further. Ultimate authority for all aspects of the regulation of the profession rests with the Legal Services Board. ${ }^{193}$ While the Law Institute ${ }^{194}$ may still set standards and rules of practice, they are subject to the approval of the Board. The Chief Executive Officer of the Board, who sits as the Legal Services Commissioner, has authority over the complaint and discipline process. ${ }^{195}$ This involves receiving complaints at first instance and making the decision in each case. ${ }^{196}$ While the Commissioner can delegate some responsibility back to the Law Institute (only with respect to the investigation of complaints), the Commissioner retains the responsibility to decide each case. ${ }^{197}$ In summary, in Victoria what few regulatory powers the Law Institute retains are subject to close supervision, and are ultimately exercised at the pleasure of the independent regulator.

The final category of reforms which bears mentioning is the inclusion of a greater role for lay participants in the regulatory process. While most Canadian law societies provide for some lay participation in the discipline process, a common feature of regulatory reforms in other jurisdictions has been to enhance the number or role of lay participants. Although this

192 Including both Scotland and England and Wales, see Part III, above.

193 Victoria, Legal Services Board, “About the Board,” online: Legal Services Board <http://www.lsb.vic. gov.au/AboutTheBoard.htm>.

194 The Victorian equivalent of the law society.

195 Victoria, Legal Services Board, "Who we are," online: Legal Services Board <http://www.lsb.vic. gov.au/WhoWeAre.htm>; Victoria, Legal Services Commissioner, "Our approach,” online: Legal Services Commissioner <http://www.lsc.vic.gov.au/OurApproach.htm> [Victoria LSC, "Our Approach"].

196 Victoria LSC, “Our Approach,” ibid.

197 Ibid. 
is not per se a regulatory regime, it is an important element of reforms - one which has been adopted even in jurisdictions which have so far been reluctant to introduce the other models of co-regulation discussed above. Lay participation takes different forms, forms which are varied enough that there is little point illustrating an example. In some systems, the situation is the same as that in Canada: limited representation of lay persons on discipline and hearing committees. ${ }^{198}$ In other jurisdictions, however, provision is made for lay representatives to form a majority on either body. ${ }^{199}$ Lay participation is also a common feature of oversight regulation mechanisms, for example in the form of a Legal Ombudsman, ${ }^{200}$ or Lay Observer. ${ }^{201}$ Whatever the role of the lay participants, there is clearly an international trend towards enhancing their number and effectiveness in the regulation of the profession.

There are, of course, serious questions to be considered about lay representatives: (1) the necessary qualifications for appointment; (2) who has authority to appoint them; and (3) their relative numbers so that they are an effective and critical mass, not just tokens. Similar debates have already taken place in the context of Judicial Appointments Committees and, for a time at least in some jurisdictions, it seemed like progress was being made. ${ }^{202}$

The foregoing is, obviously, an abstract schematic of various regulatory regimes envisioned by calibrated regulation. It is beyond the ambitions and capacity of this article to determine which of the systems might be the best option for Canada. The devil is always in the details. As MacKenzie and others have ably argued, there are potential weaknesses in every regime - complexity, inefficiency, inaccessibility, alienation, confusion, ignorance, expense, inconsistency ${ }^{203}$ — and there is always the possibility of what the economists call negative gains. ${ }^{204}$ The point we do want to emphasize, however, is that all of these systems recognize that there are a number of competing public goods at stake. Traditionally, analysts have attempted to respond to this challenge by invoking the metaphor of "balancing" 205 these goods - consumer protection, efficiency, independence, accountability, and so on. We believe that the balance metaphor underestimates the enormity of the challenge. A better,

198 See Legal Profession Act, S.N.S. 2004, c. 28, s. 7(1)(i).

199 For example, in Ireland, supra note 89.

200 As is the case in Tasmania, a jurisdiction which has introduced few other reforms to the complaints and discipline process (Law Society of Tasmania, "Complaints Against Lawyers," online: Law Society of Tasmania <http://www.taslawsociety.asn.au/web/en/lawsociety/about/complaints.html>).

As was the case under the New Zealand system prior to the reforms, described above, supra note 91 and text accompanying, which will come into effect in 2008 (New Zealand Law Society, "Complaints" (1 September 2006), online: New Zealand Law Society <http://www.nz-lawsoc.org.nz/hmcomplaints. asp>).

See e.g. Richard Devlin, A. Wayne MacKay \& Natasha Kim, "Reducing the Democratic Deficit: Representation, Diversity and the Canadian Judiciary, or Towards a 'Triple P' Judiciary” (2000) 38 Alta. L. Rev. 734.

203 MacKenzie, "Models," supra note 96; Seneviratne, Legal Profession, supra note 1 at 94-95.

204 For example, one key challenging question is how to design an effective and efficient system. Some jurisdictions have adopted a bifurcated system: a complaint as to quality goes one route while complaints about misconduct go a different route. The argument in favour of a bifurcated process is that many clients just want a decent quality of work and are not interested in discipline. However, it is not always easy to distinguish between poor quality and unacceptable conduct and the same situation might give rise to both; is a client meant to choose one over the other or must they choose both? Is there not a great likelihood of confusion?

See e.g. MacKenzie, "Models," supra note 96 at 46; Seneviratne, Legal Profession, supra note 1 at 68, 219. 
more evocative metaphor, we suggest, is juggling - there are many balls that need to be kept in the air and there is no point of equilibrium. Rather, juggling the competing public goods envisioned by regulation is a dynamic, perpetual process. Calibrated regulation recognizes this reality and is continually open to the possibility of modification and revision. ${ }^{206}$

\section{Regulatory Laggards: Why THE CANAdian Silence?}

The previous sections have analyzed both the theory and practice of regulatory reform and mapped out some of the options suggested by calibrated regulation. In this section, we reflect on why the debate has been so muted in Canada, and why we Canadians have been such regulatory laggards.

\section{A. Vocalization OF CONSUMER Dissatisfaction}

In Devlin's interviews with informants in several jurisdictions it became clear that while in some jurisdictions particular horror stories might have triggered reforms, by far the most common pattern was the increasing vocalization of consumer dissatisfaction and the repeated failures of law societies to put in place satisfactory complaints systems. ${ }^{207}$ In England, the Consumers' Association and the National Consumer Council have taken a very active interest in the poor quality of lawyers' services. ${ }^{208}$ In Australia, the Australian Federation of Consumer Organizations launched a Consumer Justice Charter. ${ }^{209}$ In Canada we do not have such cohesive consumer protection organizations. Rather, over the last ten years, consumer dissatisfaction has been focused on the problems with our health care system and, more recently, environmental concerns. To date, we have not yet witnessed a "crisis of legitimacy" for the legal profession.

Part of the reason for the continued silence of Canadian consumers may be that it is difficult to get a sense of what is really going on in terms of complaint rates. The law societies publish complaints statistics in their annual reports, but these are easily available for only the last four or five years (less in the case of some societies), which allows for only a very limited time-series analysis. There is little attention paid to complaint rates, and little

Other possibilities could be explored and debated. One suggestion is to expand the role of the judiciary in the regulation of the profession, or at least those parts of the profession that appear in court. While it is true, as MacKenzie points out, that judges probably do not want the unpleasant job of disbarring or disciplining lawyers because of their "solicitude for the ... independence of the bar" (MacKenzie, Lawyers and Ethics, supra note 71 at 27-10,27-13), the reality is that no one really relishes such a job but responsibility has to lie somewhere and distaste should not be considered to be a legitimate objection. Some modest options might be to regenerate courts' ancient "visitation rights," (MacKenzie, Lawyers and Ethics, ibid.; Hurlburt, supra note 1 at 59, 107) or make costs against lawyers more freely available by retreating from the narrowness of the Young test (Young v. Young (1990), 50 B.C.L.R. (2d) 1 (C.A.), aff'd on this point at [1993] 4 S.C.R. 3 [Young]). More radical moves would be to follow the United States where federal judges can draw on r. 11 to sanction lawyers for "filing frivolous claims or defences or otherwise needlessly increasing the costs of litigation" (Wilkins, supra note 94 at 803) or in many jurisdictions transferring full authority for discipline to independent court appointed bodies (Powell, supra note 124 at 34-35). 
formal statistical research on the topic. There is also virtually no effort to gather and present these statistics in a comparative way. ${ }^{210}$ Without readily available data, and without an interested body of researchers to study it, the public has no sense of changes in the rates and types of complaints. Where the public lacks such a basic information, there is little to mobilize them to action even if a problem may be growing.

\section{B. Disaggregation Of the Legal Profession}

The legal community is no longer the fraternity it was once thought to be. In many jurisdictions, it has been recognized that fragmentation in the profession has been pervasive in terms of class, race, gender, and ideology. ${ }^{211}$ In these jurisdictions, there has emerged sufficient numbers of lawyers who will speak out against what they see as the inequities of the regulatory system. For example, in England there is the Fabian Society. ${ }^{212}$ In Australia, it was the "new left lawyers." 213 In the U.S., it was groups like the Chicago Council of Lawyers. ${ }^{214}$ In Canada, while it is true that the profession is becoming increasingly stratified, ${ }^{215}$ and that there are undoubtedly a significant number of progressive lawyers, the reality is that few have ever mobilized to challenge the regulatory regime, instead focusing their energies on other access to justice issues such as legal aid, discrimination, equality rights, and the like.

\section{Paucity Of Scholarly Research}

Over the years several Canadian academics - some lawyers, some sociologists - have questioned the legitimacy of self-regulation but their interventions have been occasional and unsuccessful in reaching a larger audience. However, in other jurisdictions such as the U.S., Australia, and England there has been sustained and quality research measuring the success of self-regulation. ${ }^{216}$ Moreover, in some jurisdictions, New South Wales for example, Law Reform Commissions have conducted important research. ${ }^{217}$

$210 \quad$ See infra note 253.

211 See e.g. Seneviratne, “Consumer Complaints," supra note 121 at 40.

212 Arora \& Francis, supra note 95. See also Hurlburt, supra note 1 at 180-81.

$213 \quad$ Parker, JL, supra note 94 at 168.

214 Powell, supra note 124 at 39-40.

215 Arthurs, supra note 94 at 804-805, 807.

216 For a comprehensive overview of this type of work see Parker, JL, supra note 94. Examples of exemplary Canadian work include Arthurs, ibid.; Brockman \& McEwen, supra note 115; Joan Brockman, supra note 115; Charles E. Reasons, Bonnie Bray \& Duncan Chappell, "Ideology, Ethics, and the Business of Law: Varying Perceptions of the Ethics of the Legal Profession" (1989) 13 Legal Studies Forum 171; Bruce L. Arnold \& John Hagan "Self-regulatory responses to professional misconduct within the legal profession" (1994) 31:2 The Canadian Review of Sociology and Anthropology 168 .

217 See e.g. New South Wales Law Reform Commission, First Report on the Legal Profession: General Regulation and Structure, Report 31 (Sydney: The Commission, 1982); New South Wales Law Reform Commission, Scrutiny of the Legal Profession: Complaints Against Lawyers, Report 70, (Sydney: The Commission, 1993). 


\section{GOVERNMENT DISINTEREST}

In the other jurisdictions, governments, at the executive and legislative levels, have shown great interest in this issue. Despite the fact that a few Canadian jurisdictions have formal law that authorizes an active role for both the executive and the legislature in the governance of the profession, ${ }^{218}$ there is little evidence that they assert this authority.

\section{E. The Shadow OF THE COURTS}

As we have already noted on several previous occasions, for example Jabour and Pearlman, the Supreme Court of Canada has shown great solicitude for the independence of the bar. While the Court has not explicitly addressed the question of self-regulation, there is little doubt that if a government were to make significant changes to a regime of selfregulation, then it would be challenged by (some members of) the legal profession and might very well find a sympathetic ear. ${ }^{219}$

\section{F. Cadre of Professional Regulators}

Devlin's interviews indicated that in many other jurisdictions there has emerged a cadre of professional regulators who have discrete and highly sophisticated regulatory talents. Often these professionals were not lawyers but had extensive experience in other regulated fields. ${ }^{220}$ They were recruited as "agents of change" ${ }^{\text {"221 }}$ to bring fresh ideas and some regulatory heft to the system.

One noticeable variable in this regard is that many of these new regulators were women, whereas most of the senior self-regulators in the legal profession were relatively senior, older white men. Our sense was that there was certainly a tension between these groups. The new regulators expressed concerns about the "old boys club" whose loyalties (in their best light) were divided, or (in their worst light) misplaced. On the other hand, the self-regulators grumbled about "stroppy women" who were insensitive to the particularities of the legal community.

\section{G. Internal Reforms by the Canadian Legal Profession}

Although we have previously suggested that there has not been widespread discussion of the regulation of the profession by the public, the profession, or scholars, this does not mean that the profession is not keenly aware of the issues. Indeed, our impression is that certain members of the governing bodies are very much aware of what has been going on elsewhere and have been attempting, in a sense, to engage in anticipatory (perhaps preventative?) action. It seems to us that there have been considerable attempts by some law societies to enhance and improve their complaints handling processes to make them more consumer

See e.g. Legal Profession Act, 1990, S.S. 1990-91, c. L-10.1, s. 91(2); Law Society Act, R.S.O. 1990, c. L.8, s. 13. See also Hurlburt, supra note 1 at 32-33.

See e.g. Labelle v. Law Society of Upper Canada (2001), 52 O.R. (3d) 398 (Sup. Ct.) and (2001), 56 O.R. (3d) 413 (C.A.) [Labelle].

See also Seneviratne, Legal Profession, supra note 1 at 193-95.

See also Parker, OC, supra note 168 at 99-109. 
friendly; there have been efforts to make discipline processes more transparent; there have been reforms to improve the articulation of the standards of competence and quality of service, as well as civility; and there have been attempts to shift the focus from regulation as (negative) discipline to regulation as the (positive) promotion of best practices. These are not insignificant reforms. The problem, however, is that they have not been subjected to independent assessment.

\section{CODA: TRACES OF CALIBRATED REgulation}

As we have already indicated, advocates of self-regulation portray calibrated regulation as fundamentally incompatible with the norms and traditions of the Canadian legal system. If we stand back from the details, however, there is a sense that quietly, almost unnoticeably, Canada has already taken a few steps away from self-regulation towards calibrated regulation. First, it is important to note that Canada does not have a system of pure selfregulation; rather we have delegated self-regulation. Pure self-regulation would characterize private, contractually based organizations, for example, the Portuguese Water Dogs Association. In Canada, the legal profession has been statutorily authorized to regulate itself. Indeed in some jurisdictions as a matter of law, the Executive does have some authority to regulate the profession. For example, s. 13 of the Ontario Law Society Act identifies the Attorney General as "the guardian of the public interest in all matters within the scope of the Act, or having to do in any way with the practice of law." 222 In Nova Scotia, s. 7 of the Legal Profession Act provides that the Attorney Generals of Canada and Nova Scotia or their representatives must sit on Bar Council. ${ }^{223}$

Second, Courts do fulfill an important regulatory role, for example, when they impose criminal liability on lawyers for theft or fraud. More importantly they can also impose civil liability for contractual, tortious, or fiduciary breaches. One need only consider cases such as MacDonald Estate v. Martin, ${ }^{224}$ R. v. Neil, ${ }^{225}$ and 3464920 Canada Inc. v. Strother ${ }^{226}$ to witness how the Supreme Court of Canada's decisions had an impact on forcing the profession to develop its standards, particularly in the realm of conflicts of interest. As a result, the CBA has struck a task force to redraft its Code's provisions on conflicts of interest. ${ }^{227}$ In some jurisdictions, courts police the withdrawal of lawyers. ${ }^{228}$ Occasionally, but rarely, courts impose costs on lawyers if they have engaged in egregious behaviour. ${ }^{229}$ Finally, as we noted earlier, assessment officers who adjudicate fee disputes between lawyers and clients are judicial officers under the control of the judiciary and not law societies. ${ }^{230}$

Law Society Act, R.S.O. 1990, c. L.8. The scope of this authority is up for grabs. See Labelle, supra note 219.

S.N.S. 2004, c. 28.

[1990] 3 S.C.R. 1235.

2002 SCC 70, [2002] 3 S.C.R. 631.

2007 SCC 24, [2007] 2 S.C.R. 177.

Canadian Bar Association, "CBA Task Force on Conficts of Interests," online: Canadian Bar Association <http://www.cba.org/CBA/groups/conflicts/>.

Proulx \& Layton, supra note 17 at 615-20.

Young, supra note 206 at 59-62; MacKenzie, Lawyers and Ethics, supra note 71 at 27-11 to 27-13.

See also Seneviratne, Legal Profession, supra note 1 at 73-75. 
Moreover, other bodies have also assumed modest regulatory authority over lawyers. In Wilder v. Ontario Securities Commission, the Ontario Court of Appeal held that the Securities Commission can reprimand a lawyer under the authority of s. 127(1) of the Securities Act, and that this did not threaten the independence of the bar because the goal was to protect the public interest in fair and efficient capital markets. ${ }^{231}$ In Kreiger v. Law Society of Alberta, the Supreme Court of Canada held that "[T]he Attorney General's office has the ability to discipline a prosecutor for failing to meet the standards set by the Attorney General's office for prosecutors but that is a different function from the ability to discipline the same prosecutor in his or her capacity as a member of the Law Society of Alberta." ${ }^{232}$ The court also pointed out that the remedies available to each were quite different — for example, the Attorney General could not disbar a member.

Finally, and perhaps most interesting from a calibrated regulation perspective, is the situation in British Columbia. British Columbia established an Ombudsman in 1977 to hear consumer complaints about the actions of public bodies. ${ }^{233}$ From the outset, the Ombudsman has had jurisdiction to hear complaints about the conduct of professional associations in British Columbia, including the LSBC. ${ }^{234}$ The Ombudsman has in fact received between 30 and 60 complaints per year about the LSBC for the last ten years. ${ }^{235}$ Most of these have been declined or determined to be unsubstantiated, but a number have been settled as a result of consultation between the Ombudsman, the complainant, and the LSBC. ${ }^{236}$ It seems that the Ombudsman has not only practical authority to review the actions of the LSBC, but also a willingness to exercise it as well.

This has important implications for the self-regulation debate. Despite passionate objections to the very idea of calibrated regulation, ${ }^{237}$ British Columbia has been quietly, and apparently effectively, operating a functional system of oversight regulation for over thirty years. This has resulted neither in the collapse of democracy in the province, nor even in government influence over the actions of individual lawyers or the Law Society. The Ombudsman is independent of the government, and in fact, must be so in order to be effective, as they also have review powers over government bodies. As such, it is difficult to make out the argument that their powers of review represent a government incursion on the independence of the legal profession.

(2001), 53 O.R. (3d) 519 (C.A.).

2002 SCC 65, [2002] 3 S.C.R. 372 at para. 50.

Ombudsman Act, S.B.C. 1977, c. 58; Karl A. Friedmann, First Annual Report of the British Columbia Ombudsman (1979), online: British Columbia Ombudsman <http://www.ombud.gov.bc.ca/reports/ Annual_Reports/Annual\%20Report\%20of\%20the\%20Ombudsman\%20-\%201979.pdf>.

Ombudsman Act, R.S.B.C. 1996, c. 340, Sch. s. 27; British Columbia is unique in this respect. Most other provinces have an ombudsman's office, but few of them have jurisdiction extending beyond government agencies. See, for example, Ombudsman Act R.S.O. 1990, c. O.6, s. 14(1); Ombudsman Act, R.S.A. 2000, c. O-8, s. 12(1); Ombudsman Act, R.S.N.B. 1973, c. O-5. A few have authority over quasi-public bodies, such as hospitals or schools (e.g. New Brunswick for example), but only the British Columbia Ombudsman has jurisdiction to hear complaints about the Law Society or other professional associations.

Complaints estimate based on a review of annual reports of the Ombudsman British Columbia, online: British Columbia Ombudsman Reports $<$ http://www.ombudsman.bc.ca/reports/index.htm>.

Pursuant to Ombudsman Act, R.S.B.C. 1996, c. 340, s. 14.

See e.g. Finlayson, supra note 96. 
The British Columbia Ombudsman model certainly bears further study. Its long history of apparently peaceful coexistence with the Law Society should be reviewed in combination with a critical assessment of its effectiveness as a means of addressing consumer dissatisfaction, a project which is beyond the scope of this article. Whatever the long-term value of the British Columbia model, however, it provides immediate illustration of the point that the Canadian legal profession may not be as purely self-regulating as is often claimed.

These four examples are, of course, relatively modest incursions on self-regulation but they are important in that they acknowledge that pure self-regulation is a chimera, and that practically, Canada has already embarked upon the project of calibrated regulation. The real questions are whether we should go any further, and if so, in which direction(s)?

\section{Conclusion: The SPONSORS' TABLE ON THE Regulation of the Legal Profession in Canada}

In 1994, just down the road in Calgary, Arthurs delivered his celebrated "Dead Parrot" article in which he argued that "self-regulation is definitely deceased; it is pushing up the daisies; it has joined the choir invisible; it is bereft of life; it has met its maker; it is no more; it is bleeding demised." 238 In this article we have offered a more guarded argument. Selfregulation might have some virtues that help it to qualify as a public good. However, its virtues are not unqualified and it needs to be located in the context of other competing public goods; for example, guarding against conflicts of interest, access to justice, the protection and promotion of consumer interests and the promotion of competition. ${ }^{239}$ It will be tempting for many members of the legal profession to close ranks on this issue, to take it personally, to become defensive and maybe even to lash out at their critics. ${ }^{240}$ This reaction has been the predictable pattern in many other jurisdictions. The only problem is that, as a coping mechanism, it has not worked. ${ }^{241}$ Maybe it will work in Canada. But it must be remembered that Canada is a modern democracy, very different from the form of democracy in which self-regulation of the legal profession was first nurtured. ${ }^{242}$ The world has moved on, the demands of the contemporary democracy are complex, ${ }^{243}$ and globalization is a reality. It is time we moved beyond licence plate sloganeering — "self-regulation or totalitarianism" 244 — to rational analysis and assessment.

Supra note 94 at 809.

Legal Services Reform, supra note 82.

For a discussion of over the top responses to Philip Slayton's book, Lawyers Gone Bad: money, sex and madness in Canada's Legal Profession (Toronto: Viking Canada, 2007), see Gail J. Cohen, "Lawyers Gone Mad" Canadian Lawyer (7 September 2007) 3.

See e.g. Parker, JL, supra note 94, 108-39; Seneviratne, Legal Profession, supra note 1, throughout, and especially strategies of "resistance, denial ... compromise and fudge" (ibid. at 175). For other examples of the failure of the "everything is fine, leave us alone, we have it under control" mentality, see Hurlburt, supra note 1 at 95, 98-99; Wilkins, supra note 94 at 802, 812-13.

See also Parker, JL, supra note 94 at 144 advocating for a "democratic theory of public-regarding professionalism." She proceeds to suggest that this would have four dimensions: the nurturing of a professional community; encouraging elements of self-regulation; embracing competition reform; and developing institutions of state and community accountability (at 145).

See e.g. Jurgen Habermas, Between Facts and Norms: Contributions to a Discourse Theory of Law and Democracy (Cambridge, Mass.: MIT Press, 1999); Iris Marion Young, Inclusion and Democracy (New York: Oxford University Press, 2000).

MacKenzie, "Models," supra note 96 at 4. 
Thus as one concrete suggestion, we want to propose the creation of a Task Force, The Sponsors' Table on the Regulation of the Legal Profession in Canada, ${ }^{245}$ to consider the present state and future possibilities for the recalibrated regulation of the Canadian legal profession(s). Such a task force should have broad, but manageable, representation from a variety of stakeholders and it should (as the environmentalists urge us) think globally but act locally. Most importantly, it should be sufficiently well funded to enable it to commission serious and original empirical, ${ }^{246}$ historical, comparative, and conceptual research that will enable it to get beyond the rhetoric and bluster so that it can engage in "complex mapping and multiple modes of evaluation." ${ }^{247}$ Ignorance is the antithesis of bliss and accountable leadership requires imagination not intransigence. If we really do want an effective, responsive, coherent, ${ }^{248}$ and democratically defensible regulatory regime for the Canadian legal profession then we must acknowledge that calibrated regulation is knocking on our door - and that it is not the big bad wolf.

See Appendix 1.

246 One example of the problems with the present state of research is the lack of an effective central clearinghouse for statistics on discipline and complaints rates. While the societies diligently and carefully report their individual statistics every year in their Annual Reports, no real work is being done to analyze this data. The only combined source we were able to locate in our brief effort to gather some complaints information, is the patchy data contained in the yearly Federation of Law Societies of Canada (FLSC) summaries of legal profession statistics (Federation of Law Societies of Canada, "Statistics of Law Societies," online: FLSC <http://www.flsc.ca/en/lawsocieties/statisticslinks.asp >). Some years the complaints rates are reported, some years they are not. Some years what is reported is at variance with what appears in the societies' annual reports. No effort is made to analyze the data, or even to account for the variations in disciplinary procedure and data collection protocols amongst the societies. While the FLSC is to be commended for attempting to keep a comparative record of this data, it is ultimately of little analytical use.

Julia Black, "Law and Regulation: The Case of Finance" in Parker et al., RL, supra note 1,33 at 39. For a discussion of the importance of research by an inside regulator, the Legal Services Ombudsman for England and Wales, see Michael Barnes, "Monitoring and evaluating methods of regulation" in Law Society, Annual Research Conference 1994: Profession, business or trade: Do the professions have a future? (London: Law Society, 1994). It is helpful to note at this point that Hurlburt who is a staunch advocate of self-regulation also acknowledges on several occasions the dearth of empirical research (e.g., supra note 1 at $162-63,176,178$ ). The difference between our position and his is that he is willing to assert a position despite the void, whereas we would have thought that the more responsible thing to do is to seek out the evidence before taking a stand. Hurlburt justified his position in part on the basis that "there is no non-regulated or differently-regulated environment that is sufficiently comparable to form the basis of a comparison" (at 163). This was not accurate at the time (Wilkins' comprehensive "Who should Regulate Lawyers?" was published in 1992, supra note 94 and Parker's empirically thick Just Lawyers was published in 1999, supra note 94, as was Seneviratne's The Legal Profession: Regulation and the Consumer, supra note 94) and is certainly not true today. 


\section{APPENDIX I:}

\section{The Sponsors' Table on the Regulation of the Legal Profession}

In this Appendix, we will briefly describe how we came to this proposal, and delineate some key characteristics of the Sponsors' Table. The key question is, of course, where would one find an institutional home for a "structure-revising-structure" of this nature? ${ }^{249}$ There are several possibilities. Option One might be the Federation of Law Societies because it is an obvious unifying institution for the legal profession. The problems, however, are that: (1) historically it has seen its role as more of a "structure-preserving-structure" (witness its role in Finney); and (2) it is likely to be too closely aligned with the interests of the profession to be sufficiently impartial. Option Two might be a governmental review along the lines of Sir David Clementi. Such a suggestion is not unprecedented. In Ontario in 1977, the Professional Organizations Committee of the Ministry of the Attorney General issued a Report entitled Regulation of the Practice of Law in Ontario. ${ }^{250}$ The problems with this option are threefold: (1) because this is provincially based it would not encompass a national vision; (2) governments might have their own agendas that would threaten the impartiality of the Task Force; and (3) the necessary resources are likely to be beyond the resources of all but a few jurisdictions. Option Three might locate the Task Force within a Law Reform Commission initiative. For example, in 1994 the Manitoba Law Reform Commission issued a report on Regulating Professions and Occupations. ${ }^{251}$ However, again there are the problems with (1) scope, and (2) resources. Option Four, our preferred option, requires us to think outside the box and create a new type of institution, The Sponsors' Table. The idea for this comes from the recently created Sponsors' Table for Human Research Participant Protection in Canada. ${ }^{252}$ The goal of a Sponsors' Table is twofold: (1) to bring together all the key players who share a common interest in a particular area of social policy that raises questions of governance, transparency, and public accountability; and (2) to support and encourage a thoughtful consideration of the issues in question.

Mapping this onto the issue of the regulation of the legal profession we would propose the following template:

\section{GOAL}

- To bring together all the key players who have a common interest in ensuring that the regulation of the legal profession complies with the principles of good governance, transparency and accountability.

\section{REPRESENTATION}

- Federation of Law Societies Representatives.

For a specific discussion, see Roberto Mangabeira Unger, The Critical Legal Studies Movement (Cambridge, Mass.: Harvard University Press, 1986) at 94. See more generally Roberto Mangabeira Unger, False Necessity: Anti-Necessitarian Social Theory in the Service of Radical Democracy (New York: Cambridge University Press, 1987) at 341-595.

$250 \quad$ Supra note 4.

251 Manitoba Law Reform Commission, Regulating Professions and Occupations, Report No. 84 (Winnipeg: Law Reform Commission, 1994).

252 See Sponsors' Table for Human Research Participant Projection in Canada(HRPPC), online: HRPPC $<$ http://www.hrppc-pphrc.ca/english/sponsors.html >. We are indebted to Jocelyn Downie for suggesting this innovative institution to us. 


\section{Government Representatives.}

Consumer Representatives.

- Judicial Representatives.

- Canadian Law Deans Representatives.

- Regulation Specialists.

\section{TERMS}

- All members will facilitate the work of an Experts Committee to ensure that it completes its work with integrity and efficiency.

- The Table will be chaired by an "eminent person."

- The Table will meet at the request of the Chair.

- The tenure of the Table will be three years.

\section{TASKS}

- Establish an Experts Committee to conduct original empirical, historical, comparative, and conceptual research into the regulation of the legal profession.

- Reach out to other organizations that might have an interest in the regulation of the legal profession.

- $\quad$ Provide Terms of Reference to the Experts Committee.

- Facilitate the work of the Experts Committee through funding and in-kind support as appropriate and within the financial capacity of each member.

- At its request, provide advice and support to the Experts Committee. The Experts Committee has full authority with regard to the substantive elements of its work.

- Monitor the progress of the Experts Committee and require that it meets its timelines as set within its workplan.

- $\quad$ Establish a Virtual Secretariat.

- Develop a communications strategy for the Sponsors' Table and the Experts Committee.

- Make recommendations for the future regulation of the legal professions in Canada. 